\title{
THE COORDINATION COMPOUNDS Gd (III) AND Dy(III) WITH SOME
} $\beta$-DIKETONES

O. S. Berezhnytska ${ }^{1,2}$, A. E. Horbenko ${ }^{1}$, O. O. Rohovtsov ${ }^{1}$, S. S. Smola ${ }^{3}$, Ya. V. Fedorov ${ }^{1}$, O. E. Chygyrynets ${ }^{2}$, O. K. Trunova ${ }^{1}$

${ }^{1}$ V.I.Vernadsky Institute of General and Inorganic Chemistry of NAS of Ukraine, Akad. Palladin Avenue, 32/34, Kyiv 03142, Ukraine.

${ }^{2}$ National Technical University of Ukraine «Igor Sikorsky Kyiv Polytechnic Institute», 37, Peremohy Avenue, Kyiv 03056, Ukraine.

${ }^{3}$ A.V. Bogatsky Physico-Chemical Institute NASU, Lyustdorfska doroha St., 86, Odessa, Ukraine

*e-mail: berezhnytska@gmail.com

New complexes of Dy (III) and Gd (III) with b-diketones containing unsaturated and aryl substituents were synthesized. Metal polymers based on synthesized complexes were obtained by the method of radical polymerization. The composition and structure of synthesized complexes and metal polymers are established. It is shown that during polymerization the coordination environment of the central ion remains unchanged. The spectral-luminescent characteristics of the synthesized compounds were studied. The presence of water molecules in the immediate coordination environment causes a low intensity of emission of monomeric dysprosium complexes. In the luminescence spectra of metal polymers, there are bands magnetic dipole transition $\left({ }^{4} \mathrm{~F}_{9} \rightarrow{ }^{6} \mathrm{H}_{15 / 2}\right)$ and electric dipole transition $\left({ }^{4} \mathrm{~F}_{9} \rightarrow{ }^{6} \mathrm{H}_{13 / 2}\right)$. The close energies of the triplet level of the ligand and the resonant level of the dysprosium ion cause low emission characteristics of the synthesized dysprosium complexes.

Key words: lanthanides, complexes, luminescence properties, metalopolymer, gadolinium, dysprosium, $\beta$-diketones.

INTRODUCTION. High luminescence [1-6], magnetic activity [7-11], and the possibility of using as bioactive materials [12-13] and telecommunication devices [14-16] are responsible for the continuing interest in coordination compounds of lanthanides.Highly volatile stable complexes of lanthanides with a mononuclear structure play a significant role as precursors for the gas-phase synthesis of thin-film materials [17-18].
One of the most important factors influencing the properties is the correct selection of ligand systems makes it possible to avoid nonradiative energy losses during the transition from the singlet to the triplet level. Only at minimum phosphorescence and fluorescence energies can maximum luminescence intensities be achieved [19-22]. Therefore, the difference in the triplet energy level of the ligand and the resonance energy level of the lanthanide ion 
is of great importance. In general, the energy of the resonance level of the metal should be somewhat lower than the energy of the triplet level of the ligand, which neutralizes the nonradiative deactivation of the resonance level together with a high probability and efficiency of the emitting transition. The overwhelming majority of studies in this area are on lanthanide complexes emitting in the visible region of the spectrum, in particular, $\mathrm{Eu}(\mathrm{III}), \mathrm{Tb}(\mathrm{III})$, Sm(III), Nd(III), Yb(III) [12, 20, 22-26]. Although dysprosium compounds (III) are also capable of emitting in the visible region of the spectrum, such studies are limited due to the complexity of the ligand selection. Such is due to the rather high energy of the resonance level of the dysprosium ion compared to $\mathrm{Eu}$ (III) and Sm (III). Some works considered the possibility of using dysprosium complexes in the creation of white light emitters for optoelectronics. It could be realized by doping or titrating dysprosium complexes with complexes of other metals, or by mixed-ligand complexation. Thus, in the work use, bimetallic Dy: Eu complexes and trimetallic Dy: Gd: Eu complexes emit white light. Doping of gadolinium complexes with dysprosium complexes or Dy 1 Eu Dy $\backslash$ Sm HMC allowed the authors to obtain white light $[15,27-28]$. In particular, the work showed the possibility of transition from yellow through white to blue light $[29,30]$.

In addition, complexes of these metals can be used as contrast agents for MRI diagnostics. The $\mathrm{Gd}^{3+}$ and $\mathrm{Dy}^{3+}$ ions, having an optimal contrast enhancement in comparison with other paramagnetic ions, are highly toxic in the free state (10 mg / $\mathrm{kg}$ of body weight) [31]. Today, the chemical compounds DTPA (diethylenetriaminepentaacetic acid), DTPA-BMA (gadodiamide), DOTA (tetraazocyclododeca- netetraacetic acid), HP-DO3A (2-hydroxypropyltetraazododecanetriacetic acid) and, other derivatives are used as ligand systems. Their complexes with metals have paramagnetic properties, are low-molecular water-soluble, hydrophilic contrast agents that are excreted from the body by the kidneys [31-33]. The main problem of creating paramagnetic contrast agents is to find the optimal balance of high paramagnetic properties and toxicity. The ideal contrast paramagnetic should have the maximum relaxing ability in the practical absence of toxicity [34, 35]. For the rejection of macromolecular contrast agents, it is possible to create a significant improvement in the relaxation efficiency of low-molecular-weight compounds [36, 37]. In addition, polymeric systems based on non-scaling b-diketonates of lanthanides (Gd (III) and Dy (III) can be used as a precursor for rejecting contrast talkers to compete with other active materials. cell link in the molecule ligand.

It is unlikely that in the low-molecular state, $\beta$-diketones could be used as precursors for obtaining contrast agents because they are bidentate ligands. However, polymer systems based on them can compete with existing materials. The presence of a final double bond in the ligand molecule makes it an active monomer in polymerization reactions. Thus, metal complexes based on unsaturated $\beta$-diketones are active monomers in free radical polymerization reactions [38, 39].

According to the literature data, it could be pointed the areas of high scientific and technological interests of this investigations: 1 - the using both mono- and heterometallic complexes Gd (III) and Dy (III); 2 - doping of gadolinium complexes by complexes of other metals emitted in the visible and nearest-IR spectral regions. 
In this regard, in this work, we performed the synthesis, studies of the structure and properties of-diketonate complexes of Gd (III) and Dy (III) with unsaturated $\beta$-diketones and metal polymers based on them.

EXPERIMENT AND DISCUSSION OF THE RESULTS. As starting compounds were selected $\beta$-diketonate ligands (2-methyl-5-phenylpentan 1-3,5, -dion (mphrd) (2-methyl-5-biphenyl penten 1-3,5, -dione (mbphd) are shown in scheme 1.<smiles>C=C(C)C(=O)CC(O)c1ccccc1</smiles>

mphpd

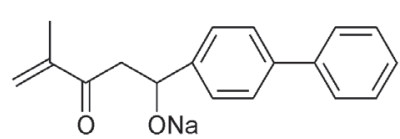

mbphpd
Scheme 1. Structure of the ligands.
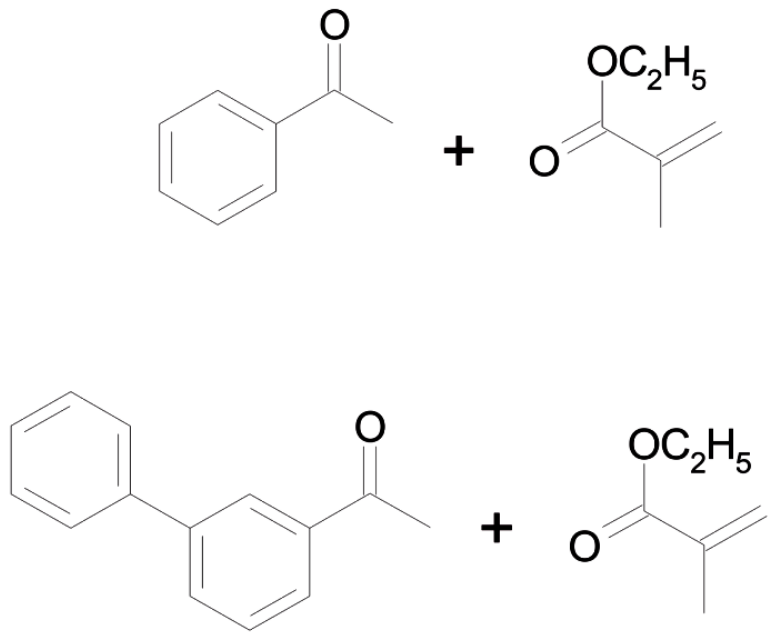

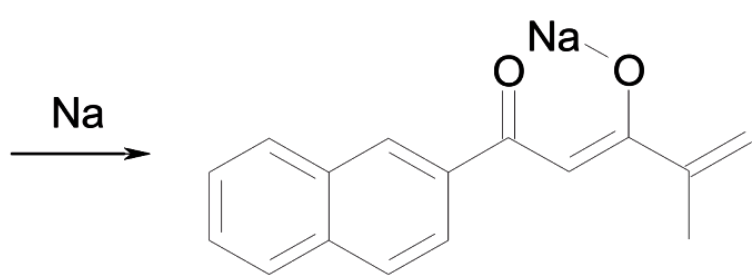

To a three-necked reactor cooled with a mixture of ice and sodium chloride, equipped with a magnetic stirrer, a reflux condenser and a dropping funnel containing 0,5 moles of sodium metal $(11,5 \mathrm{~g})$ and, $300 \mathrm{~cm}^{3}$ of dry diethyl ether, was added dropwise a solution of $0,5 \mathrm{~mol}$ $\left(99 \mathrm{~cm}^{3}\right)$ of biphenylketone and $0,5 \mathrm{~mol}\left(63 \mathrm{~cm}^{3}\right)$ of methacrylic acid ethyl ester. As a result of the reaction, a yellow precipitate fell out:

The synthesis of ligands was performed by Kleisen condensation according to the scheme presented in Fig. The method of ligand synthesis is described earlier [38, 40].

For the synthesis of $\beta$-diketonate complexes Gd (III) and Dy (III) was used dysprosium acetate (III) $\mathrm{Dy}\left(\mathrm{CH}_{3} \mathrm{COO}\right)_{3} \cdot 4 \mathrm{H}_{2} \mathrm{O}$ (c.p), gadolinium nitrate (III) $\mathrm{Gd}\left(\mathrm{NO}_{3}\right)_{3} \cdot 5 \mathrm{H}_{2} \mathrm{O}$ (c.p), sodium hydroxide $\mathrm{NaOH}$ (c.p).

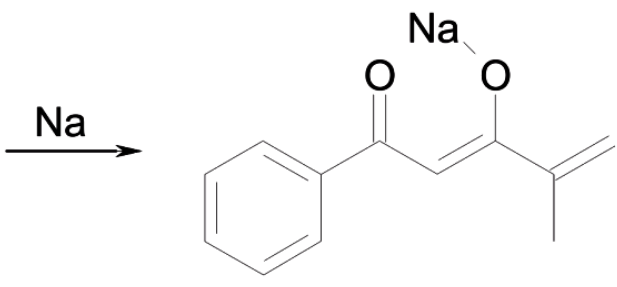

Scheme 2. Synthesis scheme of ligands.

The synthesis of complexes was performed by the interaction of aqueous solutions of metal salts with an aqueous solution of a sodium salt of the corresponding ligand at a molar ratio of reagents 1: $3(\mathrm{pH} 8-9)$ at room temperature.

$$
\begin{gathered}
\mathrm{Dy}\left(\mathrm{CH}_{3} \mathrm{COO}\right)_{3}+3 \mathrm{NaL} \rightarrow \mathrm{DeL}_{3}+3 \mathrm{CH}_{3} \mathrm{COONa} \\
\quad \mathrm{Gd}\left(\mathrm{NO}_{3}\right)_{3}+3 \mathrm{NaL} \rightarrow \mathrm{GdL}_{3}+3 \mathrm{NaNO}_{3} \\
\mathrm{~L}=\text { mphpd, mbphpd. }
\end{gathered}
$$


The resulting precipitates of the complexes were separated from the mother liquor by centrifugation, washed with water, and dried in a vacuum desiccator over anhydrous $\mathrm{CaCl}_{2}$. All synthesized complexes were yellowish.

A feature of the synthesis and purification of $\beta$-diketonates of lanthanides $\operatorname{Ln}(\beta \text {-dik })_{3}$ is the need to carry out all operations at room temperature, since with an increase in temperature, partial oligomerization of the complexes occurs (due to the presence of a reactive $\mathrm{C}=\mathrm{C}$ double bond in ligand molecules), significantly worsens their solubility. Therefore, recrystallization and additional purification of the complexes by vacuum sublimation were not carried out, although the volatility of the complexes is high enough, which was confirmed by the results of thermal analysis.

Metal polymers of gadolinium and dysprosium were obtained by the method of thermally initiated radical polymerization. Polymerization was carried out at $80^{\circ} \mathrm{C}$ in a DMF solution at a monomer (tris-diketone) concentration of $0.3 \mathrm{~mol} / \mathrm{dm}^{3}$ and an AIBN initiator concentration of $0.003 \mathrm{~mol} / \mathrm{dm}^{3}$. The obtained metal polymers were precipitated from solutions with isopropanol $[26,38]$.

The synthesized compounds were investigated by elemental analysis, FTIR, electron and fluorescence spectroscopy, thermal analysis, dynamic light scattering, and electron microscopy (SEM).

Quantum-chemical calculations of ligand molecules and metal complexes were carried out. The geometry of $\beta$-diketone molecules and their complexes with dysprosium and gadolinium was calculated using the MOPAC2016 program. For the calculation, the PM7 method was chosen, which better shows the long-range interaction of atoms in a mol- ecule, makes it possible to more accurately predict the crystal structure and heats of the formation of solids. In addition, the PM7 method calculates hydrogen bonds in more detail, which makes it possible to better describe non-covalent interactions. The use of PM7 in combination with the SPARKLE model, in which the lanthanide atom is represented as a point charge [41-42], makes it possible to obtain reliable data on the geometry of lanthanide complexes with both aliphatic and aromatic ligands.

The estimation of the enthalpy of formation of complexes was carried out on the basis of the calculated values for ligands and the corresponding values for metal complexes. The energy gap between the upper filled molecular orbital (HOMO) and the lower vacant molecular orbital (LUMO) was calculated. For each ligand and complex, the total energy, dipole moment, and ionization potential were given. The populations on the atomic orbitals and the charges on the atoms of the ligand molecules and the corresponding complexes with gadolinium and dysprosium were calculated. This allows us to conclude about the localization of the electron density and bond saturation.

Quantum-chemical calculations of ligand molecules and metal complexes based on them were carried out. The geometric structure of the ligand molecule was first optimized by the molecular mechanics method MM+ using the HyperChem program, then the resulting geometric structure was the initial one for optimization of the molecule geometry based on the SPARKLE PM7 model in the MOPAC2016 program. As a result of calculations, the following geometrically optimized structures were obtained (Fig.1). 

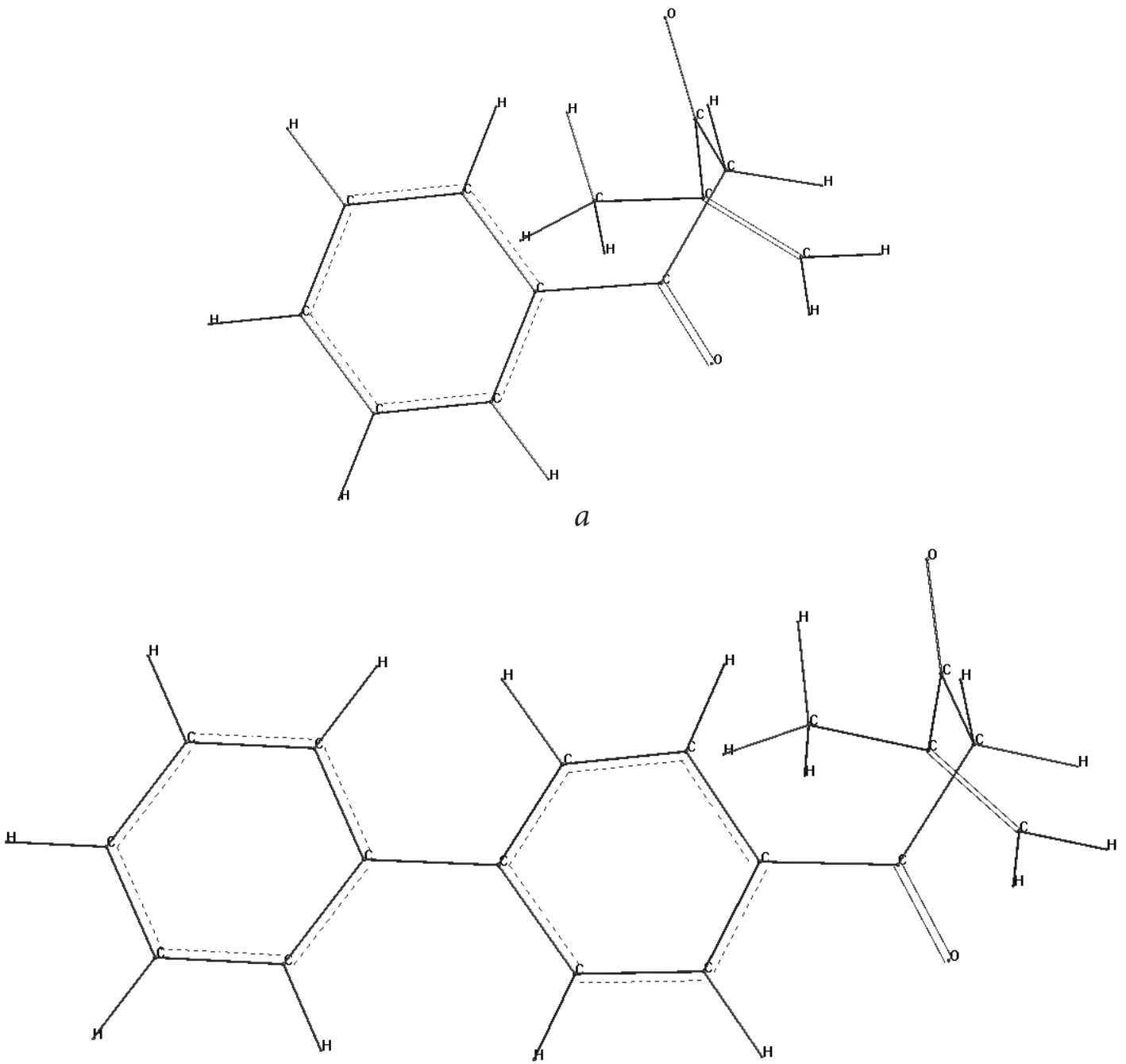

$b$

Fig. 1. Geometrically optimized structural formulas of $\beta$-diketones ( $\mathrm{a}-\mathrm{mphpd}, \mathrm{b}-\mathrm{mbphpd}$ ).

There were calculated the base energy mation, the total energy of the molecule and characteristics of the ligand molecules using bond lengths, the parameters of the electron the SPARKLE PM7 model: the enthalpy of for- populations of the ligands (Table 1).

Table 1

Characteristics of the structure and electronic populations of $\beta$-diketone molecules and $\beta$-diketone molecules.

\begin{tabular}{c|c|c}
\hline \hline Estimated parameter & mphpd & mbphpd \\
\hline Total energy $(\mathrm{eB})$ & $-2225,898$ & $-3001,148$ \\
Heat of formation $(\mathrm{kJ} / \mathrm{mol})$ & $-187,341$ & $-119,148$ \\
The dipole moment & 2,179 & 2,526
\end{tabular}




$\begin{array}{ccc} & & \text { Table 1 } \\ \mathrm{E}_{\text {homo }}(\mathrm{eV}) & -10,227 & -9,561 \\ \mathrm{E}_{\text {lumo }}(\mathrm{eV}) & -0,697 & -1,061 \\ \text { Energy gap } & 9,53 & 8,5 \\ \text { Ionization potential }(\mathrm{eV}) & 10,227 & 9,473 \\ \text { Bond lenght }(\AA) & & 1,4824 \\ \mathrm{C}_{\mathrm{RCO}}-\mathrm{R} & 1,48175 & 1,20565 \\ \mathrm{C}_{\mathrm{RCO}} \mathrm{O} & 1,20643 & 1,50799 \\ \mathrm{C}_{\mathrm{RCO}}-\mathrm{C}_{\mathrm{CH} 2} & 1,50965 & 1,5115 \\ \mathrm{C}_{\mathrm{CH} 2}-\mathrm{C}_{\mathrm{CO}} & 1,51066 & 1,2051 \\ \mathrm{C}_{\mathrm{CO}}-\mathrm{O} & 1,20514 & 1,4891 \\ \mathrm{C}_{\mathrm{CO}}-\mathrm{C}_{\mathrm{C}-\mathrm{CH} 2} & 1,48905 & \\ \text { Atomic unit of charge: } & & 0,4953 /-0,1693 \\ \mathrm{Q} \mathrm{C}_{\mathrm{RCO}} / \mathrm{Q}_{\mathrm{CR}} & 0,4832 /-0,1651 & 0,4953 /-0,4460 \\ \mathrm{QC}_{\mathrm{RCO}} / \mathrm{QO} & 0,4832 /-0,4296 & -0,501 / 0,4814 \\ \mathrm{QC}_{\mathrm{CH} 2} / \mathrm{QC} & -0,4988 / 0,4734 & 0,4814 /-0,4311 \\ \mathrm{Q} \mathrm{CO}_{\mathrm{CO}} / \mathrm{QO} & 0,4734 /-0,4309 & 0,4814 /-0,0406 \\ \mathrm{QC}_{\mathrm{CO}}-\mathrm{QC}_{\mathrm{C}-\mathrm{CH} 2} & 0,4734 /-0,0605 & \end{array}$

Analyzing the value of the heats of formation of ligands, we see that the process of formation of molecules is exothermic, we observed this in the process of synthesis. As mentioned above, while mixing the starting reagents, the reaction mixture was heated. With an increase in the volume of the ligand, upon going from phenolic to biphenyl substituent, the heat of formation increases from $-187.341 \mathrm{~kJ} / \mathrm{mol}$ (mphpd) to $-119.148 \mathrm{~kJ} / \mathrm{mol}$ (mbphpd). The dipole moment for mbphpd (2.526) is slightly higher than for mphpd (2.179), which may be due to the different distribution of electron charges in the biphenyl molecule. The bond lengths in both molecules are comparable, as expected, due to the same nature of the substituents. The negative charge in both ligands is concentrated on oxygen atoms. Having calculated the energies of the highest filled molecular orbital $\left(\mathrm{E}_{\mathrm{HOMO}}\right)$ and the lowest vacant molecular orbital ( $\left.\mathrm{E}_{\mathrm{LUMO}}\right)$, we can conclude that these com- plexes will exhibit weak electron-withdrawing properties, for mphpd and mbphpd $\mathrm{E}_{\mathrm{LUMO}}=$ $-0.697 \mathrm{eV}$ and $-1.061 \mathrm{eV}$, respectively.

The performed quantum-chemical calculations made it possible to geometrically optimize the molecules of $\beta$-diketonate complexes of gadolinium and dysprosium (Fig.2)

As can be seen from Fig. and fig. all presented complex compounds have a non-planar structure, and the ligands are located in different planes. All ligands are bidentate and are coordinated to the central ion (c.i) by two oxygen atoms, which is consistent with previous studies and literature data. Comparing the average bond lengths of lanthanides - oxygen, we see that in dysprosium complexes it is less - $2.2241 \AA$ versus $2.2381 \AA$ for gadolinium complexes (Table 1). Such a change in the bond length can be explained both by the effect of lanthanide compression and by different populations of orbitals. 


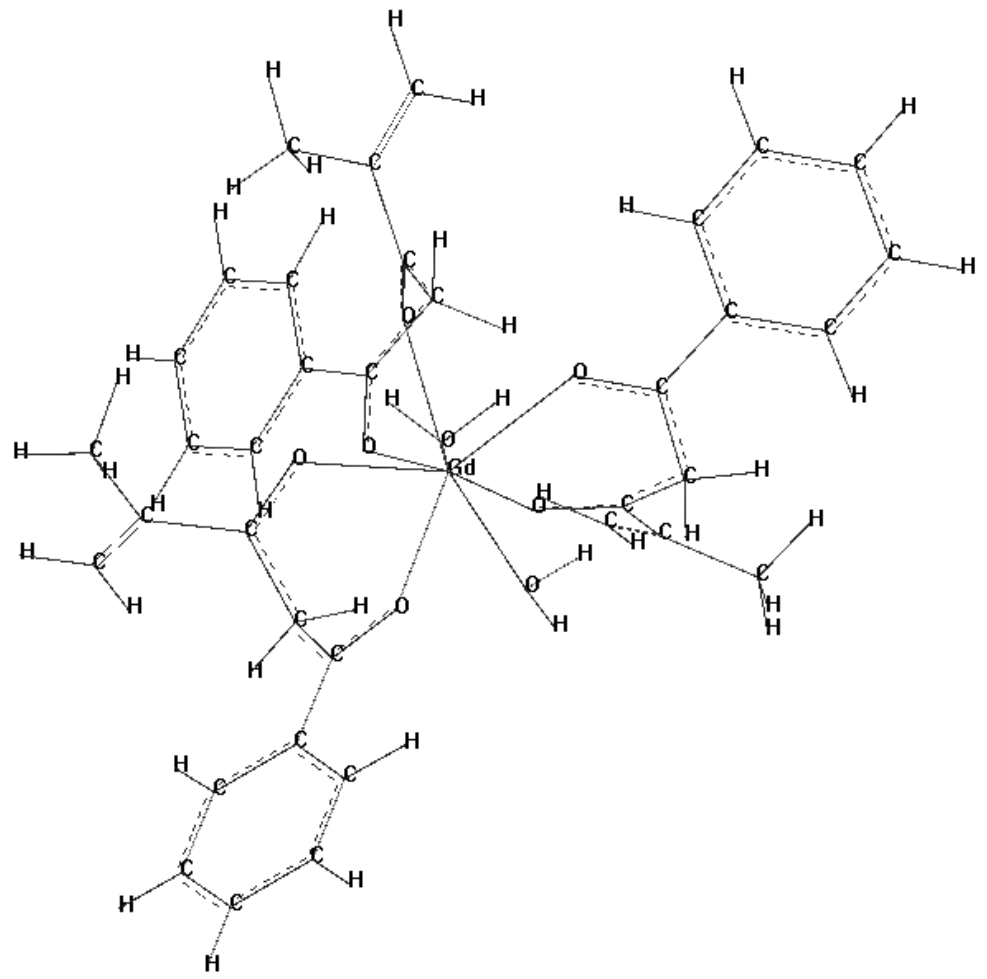

$a$

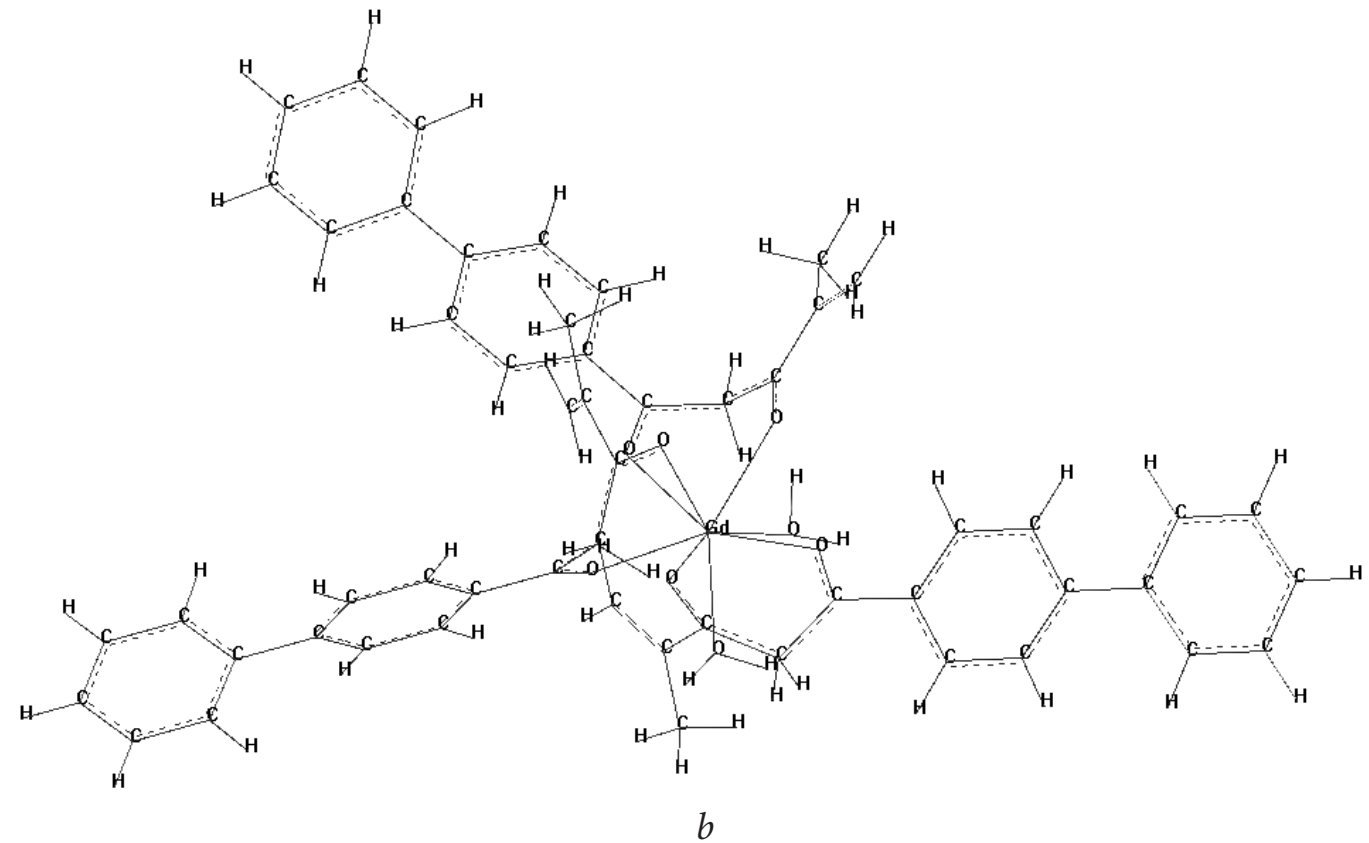

Fig. 2. Geometrically structure of $\beta$-diketonate complexes of $\mathrm{Gd}(\mathrm{mphpd})_{3} \cdot 2 \mathrm{H}_{2} \mathrm{O}(\mathrm{a})$ and $\mathrm{Gd}(\mathrm{mbphpd})_{3}$ - $2 \mathrm{H}_{2} \mathrm{O}(\mathrm{b})$. 


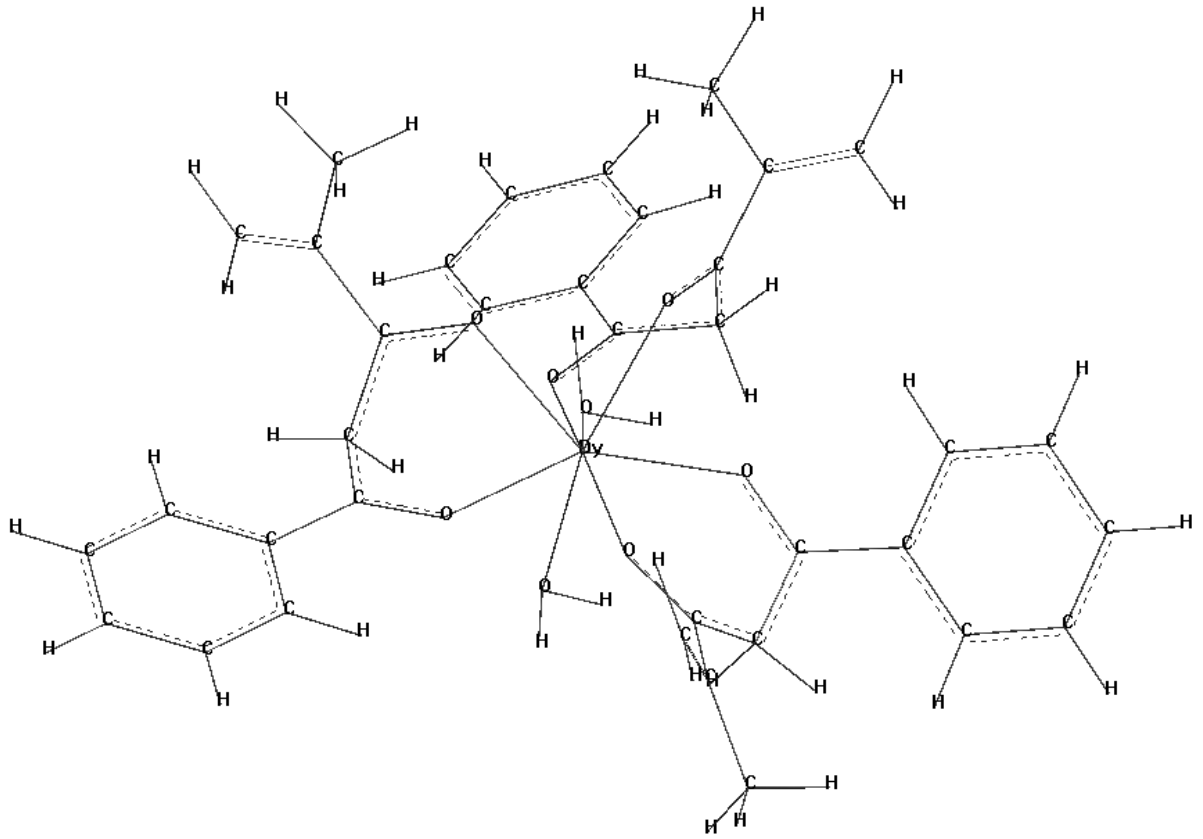

$a$

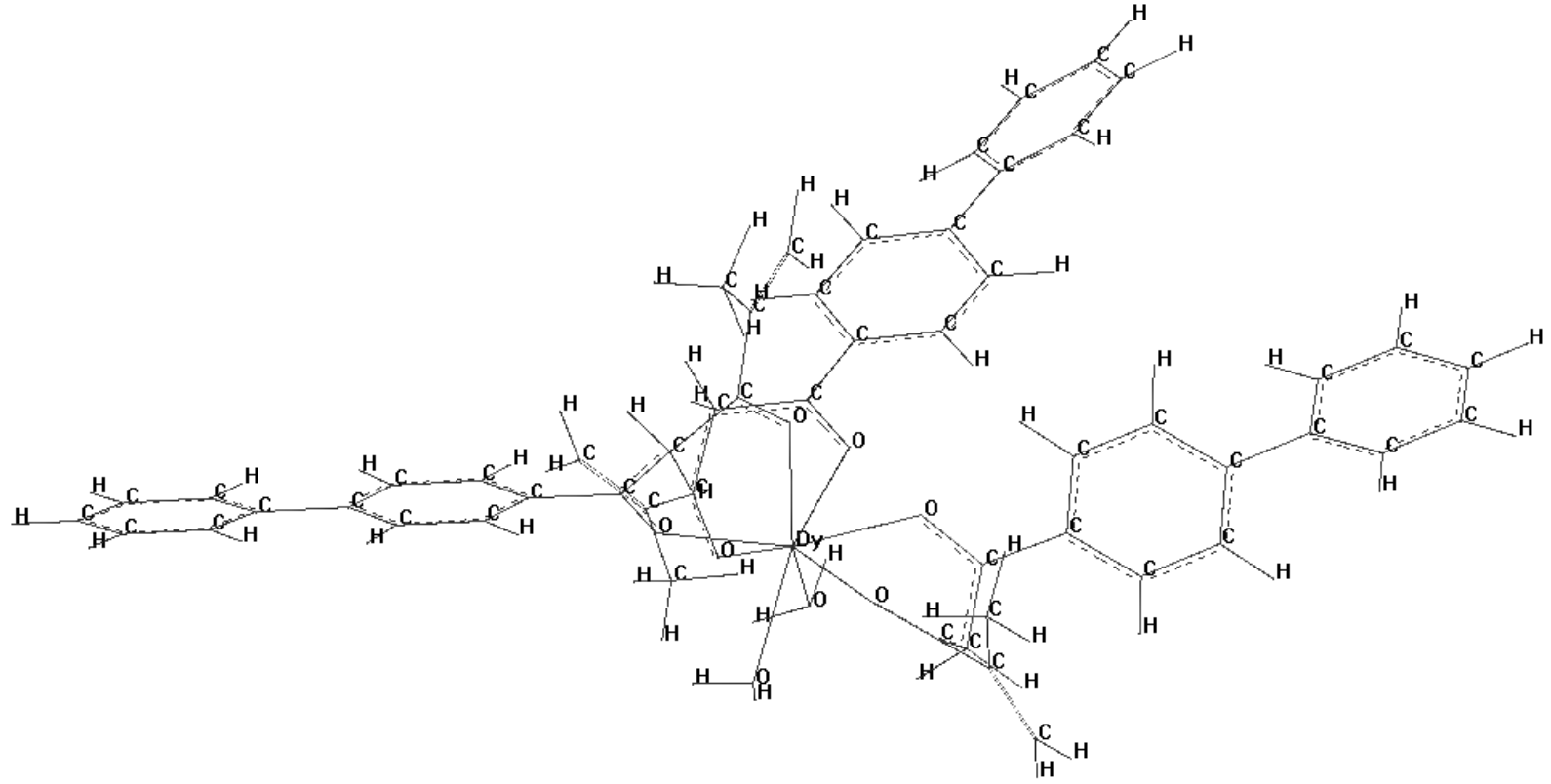

$b$

Fig. 3. Geometrically structure of $\beta$-diketonate complexes of $\mathrm{Dy}(\mathrm{mphpd})_{3} \cdot 2 \mathrm{H}_{2} \mathrm{O}(\mathrm{a})$ and $\mathrm{Dy}(\mathrm{mbphpd})_{3}$ $\cdot 2 \mathrm{H}_{2} \mathrm{O}(\mathrm{b})$. 
Analyzing the value of the heats of formation of complexes, it can be noted that negative values are observed for complexes based on mphpd, and positive for complexes of Gd and Dy with mbphpd - +106.474 and $+185.622 \mathrm{~kJ} / \mathrm{mol}$, respectively. For the complexes $\mathrm{Gd}(\mathrm{mbphpd})_{3}$ - $2 \mathrm{H}_{2} \mathrm{O}$ and $\mathrm{Dy}(\mathrm{mbphpd})_{3} \cdot 2 \mathrm{H}_{2} \mathrm{O}$, we have a positive value of the heats of formation, indicating that the formation of complexes occurs with heat absorption, that is, the process is endothermic.

As can be seen from the energies of the highest filled molecular orbital (EHOMO) and the lowest vacant molecular orbital (ELUMO), the complexes exhibit electron-withdrawing properties. EHOMO behaves like an electron donor, while ELUMO behaves like an acceptor. The difference between the energies of EHOMO and ELUMO represents the HOMO-LUMO energy gap. If a molecule has a small energy gap, it shows high reactivity.

The ionization potential and the parameters of the electron affinity were determined using the energies of $\mathrm{E}_{\text {номо }}$ and ELUMO, namely,
$\mathrm{I}=-\mathrm{E}_{\text {Номо }}$ and $\mathrm{A}=-\mathrm{E}_{\mathrm{LUMO}}$, where $\mathrm{I}$ is the ionization energy and $\mathrm{A}$ is the electron affinity. In ionization by potential, a physical quantity is understood, which is determined by the ratio of the smallest energy required for the single ionization of an atom (or molecule) in the ground state to the charge of an electron. Ionization potential is a measure of ionization energy equal to the work of detachment of an electron from an atom or molecule and characterizes the bond strength of an electron in an atom or molecule.

As can be seen from the table, all calculated parameters correlate quite well in the case of pairs of complexes with the same ligands, namely: Gd(mphpd) ${ }_{3}$ and Dy(mphpd) ${ }_{3}$, Gd(mbphpd $)_{3}$ and Dy(mbphpd $)_{3}$. Somewhat lower values of the series parameters for dysprosium complexes, including the length of the lanthanide-oxygen bond, which is determined both by the different electronic structure of c.i. and by a decrease in the ionic radius of the latter. All calculated parameters of the complexes are shown in table 2.

Table 2

Characteristics of the structure and electronic populations of complexes.

\begin{tabular}{|c|c|c|c|c|}
\hline Estimated parameter & $\mathrm{Gd}(\mathrm{mphpd})_{3}$ & $\mathrm{Gd}(\mathrm{mbphpd})_{3}$ & Dy $(\text { mphpd })_{3}$ & Dy(mbphpd $)_{3}$ \\
\hline Total energy (eV) & $-6675,884$ & $-8230,603$ & $-6675,479$ & $-8872,074$ \\
\hline Heat of formation $(\mathrm{kJ} / \mathrm{mol})$ & $-105,962$ & 106,474 & $-26,744$ & 185,622 \\
\hline The dipole moment & 0,696 & 0,576 & 0,723 & 0,572 \\
\hline $\mathrm{E}_{\text {homo }}(\mathrm{eV})$ & $-9,249$ & $-8,932$ & $-9,244$ & $-8,929$ \\
\hline $\mathrm{E}_{\text {lumo }}(\mathrm{eV})$ & $-0,548$ & $-0,868$ & $-0,558$ & $-0,872$ \\
\hline Energy gap & 8,701 & 8,064 & 8,686 & 8,057 \\
\hline Ionization potential $(\mathrm{eV})$ & 9,249 & 8,931 & 9,244 & 8,929 \\
\hline Electron affinity $(\mathrm{eV})$ & 0,548 & 0,868 & 0,558 & 0,872 \\
\hline Hardness $(\mathrm{eV})$ & 4,3505 & 4,032 & 4,343 & 4,0285 \\
\hline Softness (eV) & 0,23 & 0,248 & 0,2302 & 0,248 \\
\hline Bond length $\mathrm{l}_{\mathrm{av}} \mathrm{O}-\mathrm{Ln}(\hat{\AA})$ & 2,2355 & 2,2454 & 2,2266 & 2,2242 \\
\hline
\end{tabular}


The elimination of adsorbed water occurs at $70^{\circ} \mathrm{C}$, further dehydration of dysprosium and gadolinium complexes with methacroylacetophenone $\operatorname{Ln}(\mathrm{mphpd})_{3}$ occurs at temperatures of $1650 \mathrm{C}$ and $1900 \mathrm{C}$, respectively, and is accompanied by significant endoeffects. At the same time, there is a loss of sample mass by $4.4 \%(\mathrm{mop}=4.7 \%)$ for Dy $(\mathrm{mphpd})_{3}$ and $4.6 \%$ for $\mathrm{Gd}(\mathrm{mphpd})_{3}(\mathrm{mop}=4.8 \%)$, which corresponds to the elimination of two coordinated water molecules. Endoeffects at temperatures of $198^{\circ} \mathrm{C}\left(\mathrm{Dy}(\mathrm{mphpd})_{3}\right)$ and $189^{\circ} \mathrm{C}\left(\mathrm{Gd}(\mathrm{mphpd})_{3}\right)$ are due to the melting of the complexes (the weight loss in this case is $2 \%$ and $1.8 \%$, respectively). A further increase in temperature is accompanied by small exoeffects $\left(235^{\circ} \mathrm{C}\right.$ for Dy and $242^{\circ} \mathrm{C}$ for $\mathrm{Gd}$ ) and an insignificant weight loss, which corresponds to the polymerization of the complexes. With a further increase in temperature $\left(>240^{\circ} \mathrm{C}\right)$ in both compounds, the destruction of the complex occurs by the elimination of one molecule of methacroylacetophenone, which is accompanied by exothermic effects at 275 and $278^{\circ} \mathrm{C}$, respectively [43].

In the temperature range $285-500^{\circ} \mathrm{C}$, the thermal destruction of both complexes proceeds with the generation of heat; the thermogram contains exoeffects at 293,332, 380, $442^{\circ} \mathrm{C}$ for $\mathrm{Dy}(\mathrm{mphpd}) 3_{3} ; 305,345,380^{\circ} \mathrm{C}$ for $\mathrm{Gd}(\mathrm{mphpd})_{3}$ ) and a significant loss in the mass of the samples, which is due to the decomposition of organic fragments of the molecule. The total weight loss in the investigated temperature range for both complexes is $\sim 80 \%$. The general view of the thermograms of complexes based on mbphpd is practically the same. The only difference are in the lower dehydration temperature of complexes $150^{\circ} \mathrm{C}(\mathrm{Dy}(\mathrm{mbph}-$ $\mathrm{pd})_{3}$ and $165^{\circ} \mathrm{C}-\mathrm{Gd}(\mathrm{mbphpd})_{3}$. The results of elemental analysis and DTA made it possible to establish that the composition of the synthesized complexes corresponds to the formula $\mathrm{LnL}_{3} \cdot 2 \mathrm{H}_{2} \mathrm{O} \mathrm{Ln}=\mathrm{Gd}, \mathrm{Dy}, \mathrm{L}=$ mphpd, mbphpd.

Thermograms of methalopolymers differ significantly. A significant endoeffect at $175-185^{\circ} \mathrm{C}$ is due to the elimination of water molecules, which are located in the cavities of the metalopolymer. Upon further heating, we observe an exoeffect at $350^{\circ} \mathrm{C}$ and a significant weight loss $(\Delta m \approx 30 \%)$, which may be due to the destruction of the metalopolymer structure. Endoeffect at $440^{\circ} \mathrm{C}$ may be due to steric rearrangements in the polymer structure. Further heating of the sample is accompanied by small exoeffects at 480 and $490^{\circ} \mathrm{C}$ with practically no change in its weight, which indicates the stability of the polymer at high temperatures and the absence of destruction of the polymer structure.

The investigating of the results of thermal analysis, we can say that the dehydration of all synthesized monomeric complexes with aryl substituents occurs in the range $120-130^{\circ} \mathrm{C}$, which indicates the outer-sphere coordination of water molecules. Minor endoeffects in the region of $195-207^{\circ} \mathrm{C}$ are due to the melting of the complexes (the weight loss is insignificant, up to $2.5 \%$ ). An increase in temperature is accompanied by a number of exoeffects in the range $240-290^{\circ} \mathrm{C}$, which corresponds to the elimination of one ligand molecule, the weight loss, in this case, is in the range of $24-28 \%$, which is in good agreement with the theoretically calculated). Further exoeffects after $300^{\circ} \mathrm{C}$ correspond to the destruction of the organic part of the molecule, and a significant loss of mass. In general, the weight loss in the investigated temperature range is $75-85 \%$. The decomposition mechanism for similar coordination compounds was described in detail 
by the authors earlier [43-45]. Weight loss in this temperature range is accompanied by an insignificant endoeffect and corresponds to two coordinated water molecules, together with elemental analysis allows us to state that the composition of monomeric complexes corresponds to the formula $\mathrm{LnL}_{3} \cdot 2 \mathrm{H}_{2} \mathrm{O}$, where $\mathrm{Ln}=\mathrm{Gd}(\mathrm{III}), \mathrm{Dy}(\mathrm{III}) \mathrm{L}=$ mphpd, mbphhd.

IR spectra were recorded on a Specord M80 spectrometer in the range of $400-4000 \mathrm{~cm}^{-1}$ in $\mathrm{KBr}$ pellet. There are bands of symmetric and asymmetric stretching vibrations of the bond $v(\mathrm{C}-\mathrm{O})$ and $v(\mathrm{C}-\mathrm{C})$ in the IR spectra of the synthesized metal $\beta$-diketonates in the range

of $1500-1700 \mathrm{~cm}^{-1}$. Since there is delocalization of the electron density in the diketonate fragment, the stretching vibration bands also occupy an intermediate place between the stretching vibrations of single $\mathrm{CO}$ and $\mathrm{CC}$ and double $\mathrm{C}=\mathrm{O}$ and $\mathrm{C}=\mathrm{C}$ bonds [45-47]. It is known that a band with a higher frequency $\left(\sim 1575-1590 \mathrm{~cm}^{-1}\right)$ corresponds to a symmetric stretching vibration of the bond (CO), and with a lower frequency $\left(\sim 1520-1555 \mathrm{~cm}^{-1}\right)-$ to an asymmetric stretching vibration of a bond (CC). However, quite often these bands are observed as one wide line split into several components.

Table 3

Characteristic frequencies in IR spectra of Dy and Gd complexes with $\beta$-diketones $\left(\mathrm{cm}^{-1}\right)$.

\begin{tabular}{|c|c|c|c|c|c|c|}
\hline Complex & $\begin{array}{l}v(\mathrm{M}-\mathrm{O}) \\
+\delta_{\text {hel.ring }}\end{array}$ & $v_{\mathrm{as}}(\mathrm{CO})$ & $v_{\text {as }}(\mathrm{CC})$ & $v_{s}(\mathrm{CO})$ & $\begin{array}{l}v_{s}(\mathrm{CC})+ \\
v_{s}(\mathrm{CPh})\end{array}$ & $v\left(\mathrm{H}_{2} \mathrm{O}\right)$ \\
\hline$\overline{D y(m p h p d})_{3}$ & $\begin{array}{l}415,422,438, \\
475,520\end{array}$ & 1427 & 1555 & 1590 & 1640,1660 & 32303414 \\
\hline$\left[\mathrm{Dy}(\mathrm{mphpd})_{3}\right]_{\mathrm{n}}$ & $\begin{array}{l}410,425 \\
485,515\end{array}$ & 1430 & 1560 & 1590 & 1640 & 3380 \\
\hline $\mathrm{Gd}(\mathrm{mphpd})_{3}$ & $\begin{array}{l}415,420,433 \\
473,518\end{array}$ & 1440 & 1540,1557 & 1595 & 1645,1652 & 3350 \\
\hline$\left[\mathrm{Gd}(\mathrm{mphpd})_{3}\right]_{\mathrm{n}}$ & $\begin{array}{l}412,425 \\
490,515\end{array}$ & 1445 & 1550 & 1590 & 1658 & 3380 \\
\hline Dy(mbphhd $)_{3}$ & $\begin{array}{l}456,470 \\
489,520\end{array}$ & 1403,1415 & 1542,1560 & 1610 & 1680 & 3425 \\
\hline$\left[\mathrm{Dy}(\mathrm{mbphhd})_{3}\right]_{\mathrm{n}}$ & $\begin{array}{l}450,468, \\
470,480,515\end{array}$ & 1410 & 1550 & 1610 & 1670 & 3420 \\
\hline $\mathrm{Gd}(\mathrm{mbphhd})_{3}$ & $\begin{array}{l}455,462, \\
478,490,514\end{array}$ & 1405 & 1540,1560 & 1612 & 1675 & 3430 \\
\hline$\left[\mathrm{Gd}(\mathrm{mbphhd})_{3}\right]_{\mathrm{n}}$ & $\begin{array}{l}455,470, \\
485,500,520\end{array}$ & 1400 & 1550 & 1605 & 1670 & 3430 \\
\hline
\end{tabular}

Some inequality of ties, despite the delocalized system, is still present. This is especially noticeable in the region of $400-600 \mathrm{~cm}^{-1}$, it is here that there are stretching vibrations of the
M-O bond and deformation vibrations of a careless ring. Therefore, in this region of the spectrum, there is a significant number, mainly of low- intensity bands. This is due to the different 
nature of the bonds, the electronic structure of the complexing ion, and the influence of the substituent in the diketonate fragment. For the same reason, in the $1400-1600 \mathrm{~cm}^{-1}$ region, we observe an insignificant splitting of the spectral lines assigned to $v_{\mathrm{as}}(\mathrm{CC})$ and $v_{\mathrm{s}}(\mathrm{CO})$. However, this inequality of bonds is not significant; therefore, it is inappropriate to speak of a significant deformation of the coordination polyhedron.

For all synthesized complexes in the region of $3200-3400 \mathrm{~cm}^{-1}$, a broadband is observed, which corresponds to valence vibrations of coordinated water molecules. Unfortunately, based on the results of IR spectra, it is impossible to separate coordinated and adsorbed water molecules, however, based on the width of this band, we can confidently conclude that the synthesized compounds are not hydroxo complexes, this fact is also confirmed by their rather high solubility in organic solvents, in particular, DMSO, DMF, chloroform.

In general, the IR spectra of metal polymers table 3 are similar to the corresponding monomeric complexes, but there is an insignificant long-wavelength shift of the bands corresponding to characteristic vibrations, which suggests a weakening of the metal-ligand bond for polymers as compared to the monomeric complex. For polymers, the MO stretching vibration bands have already been split into several components, confirming a more ordered structure of metal polymers as compared to the monomeric complex.

Thus, the shape and position of the bands in the IR spectra of monomeric and metal-polymer complexes of gadolinium and dysprosium are characteristic of bidentate-coordinated $\beta$-diketonate ligands with delocalized $\pi$-bonds in the chelate rings (Table 3 ). The displacement of the position of the bands of metal polymers compared to monomers to the low-frequency region indicates a weakening of the metal-ligand bond, which is due to a higher part of covalence. Taking into account the data of IR spectroscopy and DTA, the schematic structure of complexes of lanthanides with $\beta$-diketones (for example, methacroylacetophenone) can be depicted as follows:

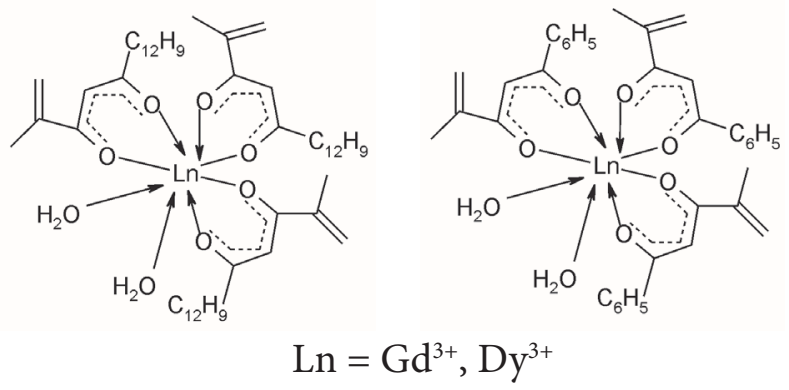

In the diffuse reflectance and electronic absorption spectra of the synthesized gadolinium and dysprosium compounds, there are broadened bands in the range of $230-400 \mathrm{~cm}^{-1}$, which can be attributed to the $\pi \rightarrow \pi^{\star}$ electronic transitions from the ground (S0) to the excited state (S1) of ligand molecules. The shift (70$100 \mathrm{~nm}$ ) and broadening of this band, in comparison with its position for free ligands, may indicate both the realization of the complexation process and the influence of the electronic structure of the metal and substituents in the dicarbonyl fragment, as well as the superposition of the $\pi \rightarrow \pi^{*}$ bands the electronic transition and the charge transfer band from the ligand to the metal, the different nature of these transitions (Fig. 4). The lower intensity of the band of metallopolymers compared to monomers is due to the shielding of neighboring molecules by polymer fragments due to their larger size compared to monomeric systems. Since the main transitions of the gadolinium ion are observed in the UV region, it is impos- 
sible to identify them for these compounds, since they overlap with the intense charge transfer band from the metal to the ligand. The shape of the band in both monomeric gadolinium complexes is the same, but in the case of the biphenyl substituent, we observe a shift of the band by $20 \mathrm{~nm}$, which is due to different energies of the ligands and, accordingly, different positions of the charge transfer band. The broadening of the band for metal polymers is due to exchange interactions in the polymer; however, it should be noted that the position of the maxima in the monomer and polymer are unchanged, and an insignificant shift by $2-4 \mathrm{~nm}$ is due to additional exchange interactions in the polymer structure.

The similar shape and position of this band both in the diffuse reflectance spectra of the compounds and in the EAS indicates the similarity of the structure of the complexes in solution and in the polycrystalline state. In the diffusion reflection spectra of dysprosium coordination compounds, a set of bands with ${ }^{6} \mathrm{H}_{13 / 2}$ of the main multiplet is observed Table 4 .

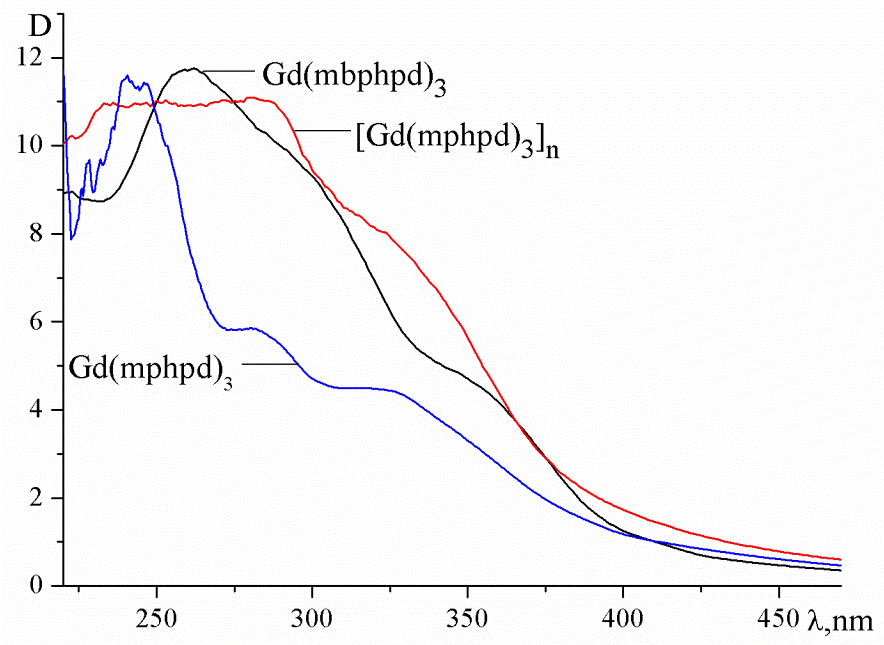

Fig. 4. Reflectance spectra of gadolinium complexes.

Table 4

The energy of the transition in the reflective spectra of the dysprosium (III) coordination compounds.

\begin{tabular}{lllll}
\hline \hline Transition & Dy $(\text { mphpd })_{3}$ & {$\left[\text { Dy }(\text { mphpd })_{3}\right]_{\mathrm{n}}$} & Dy $(\text { mbphpd })_{3}$ & {$\left[\text { Dy }(\mathrm{mbphpd})_{3}\right]_{\mathrm{n}}$} \\
\hline${ }^{6} \mathrm{H}_{13 / 2 \rightarrow} \rightarrow{ }^{6} \mathrm{~F}_{3 / 2}$ & 756 & 757 & 757,763 & 758 \\
${ }^{6} \mathrm{H}_{13 / 2 \rightarrow} \rightarrow{ }^{6} \mathrm{~F}_{5 / 2}$ & 806 & 808 & 807 & 810 \\
${ }^{6} \mathrm{H}_{13 / 2 \rightarrow} \rightarrow{ }^{6} \mathrm{~F}_{7 / 2}$ & 906 & 909 & 907 & 910 \\
${ }^{6} \mathrm{H}_{13 / 2 \rightarrow} \rightarrow{ }_{9 / 2},{ }^{6} \mathrm{H}_{7 / 2}$ & 1097 & 1099 & 1100 & 1100 \\
${ }^{6} \mathrm{H}_{13 / 2 \rightarrow} \rightarrow{ }^{6} \mathrm{~F}_{11 / 2,}{ }^{6} \mathrm{H}_{9 / 2}$ & 1287 & 1289 & 1289 & 1290 \\
${ }^{6} \mathrm{H}_{13 / 2 \rightarrow} \rightarrow{ }^{6} \mathrm{~F}_{13 / 2,} \mathrm{H}_{11 / 2}$ & 1697 & 1700 & 1699 & 1702 \\
\hline \hline
\end{tabular}


The shape and position of the bands in the diffuse reflectance spectra of monomeric and polymer complexes are similar (Fig.5) indicate a similar structure of the coordination polyhedron in monomeric and metal-polymer complexes. An insignificant shift of the bands to longer wavelengths, and in some places their broadening indicates a weakening of the bond of the central ion with the ligand in polymers, and on the presence of exchange interactions in the macromolecules of the metal chelating agents. Schematically, the structure of the elementary unit of metal polymers could be depicted as follows:

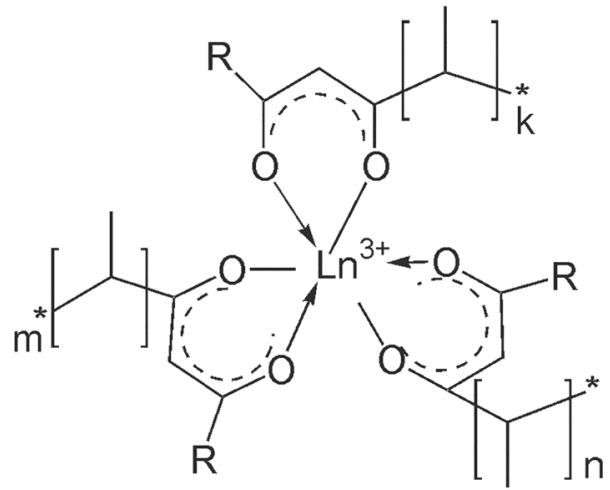

$$
\text { Ln=Gd, Dy; } \mathrm{R}=\mathrm{C}_{6} \mathrm{H}_{5}, \mathrm{C}_{12} \mathrm{H}_{9}
$$
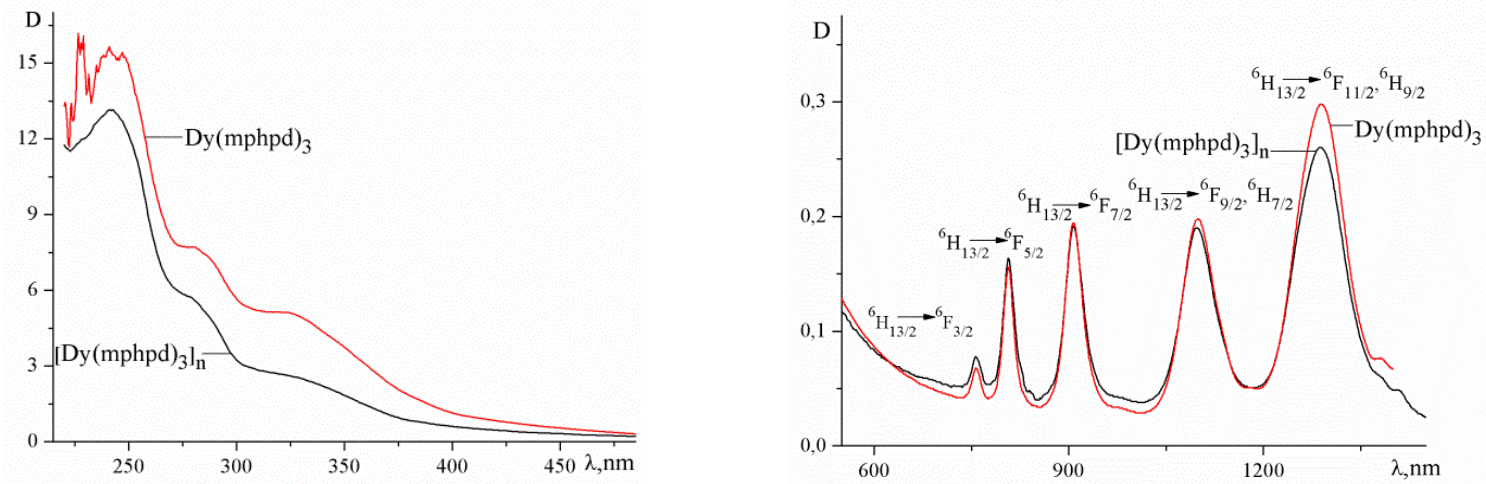

Fig. 5. Diffuse reflection spectra of dysprosium compounds.

Unfortunately, the method of electron spectroscopy does not allow one to establish the symmetry or structure of the coordination polyhedron for the studied coordination compounds. However, based on previous studies of similar complexes of europium, neodymium, samarium, and the ability to the splitting of spectral lines, such complexes have non-cubic symmetry of the ligand field.
Therefore, in order to determine the energy of the singlet and triplet levels of the ligands, the fluorescence and phosphorescence spectra of gadolinium-containing complexes were studied (Fig. 6). The excitation and luminescence spectra of solid complexes were recorded on a spectrofluorimeter Fluorolog FL 3-22, Horiba Jobin Yvon (Xe-lamp 450 W) with a light filter OS 11, with their subsequent 
adjustment taking into account the radiation distribution of the xenon lamp and the sensitivity of the photomultiplier tube. The InGaAs (DSS-IGA020L, Electro-Optical Systems, Inc, USA) photoresistance was used as a radiation receiver for the IR region when cooled to liquid nitrogen temperature.

In general, ligand energies can be determined by recording the phosphorescence and fluorescence spectra of gadolinium, lanthanum, and lutetium complexes, which is due to the empty (lanthanum), half-filled (gadolinium), and completely filled (lutetium) f shell of these ions. For methacroylacetophenone, we recorded the fluorescence spectra of both the ligand itself and all the above complexes based on it. The results obtained are in good agree-

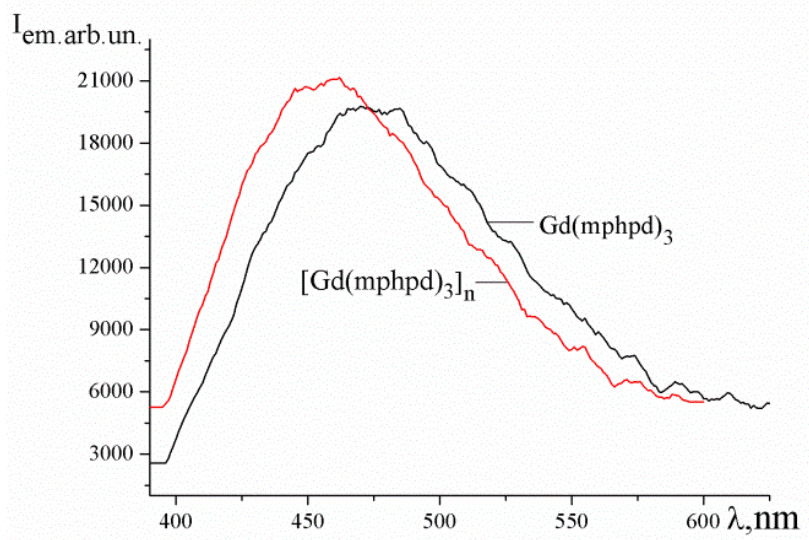

ment with each other, and the obtained energy value is the same in all cases.

Subsequently, to establish the energy of the singlet and triplet levels of the ligand, we chose the Gd (III) complexes, which is due to several reasons, namely: the high position of the resonance level of $\mathrm{Gd}^{3+}\left(32000 \mathrm{~cm}^{-1}\right)$ in comparison with the triplet level of the ligands, prevents energy transfer from the organic part of the complex to the lanthanide ion and the presence of a heavy paramagnetic ion increase the efficiency of intersystem conversion due to mixing of singlet and triplet levels («paramagnetic effect») and, as a consequence, the ratio of the phosphorescence quantum yield to the fluorescence quantum yield (>100).

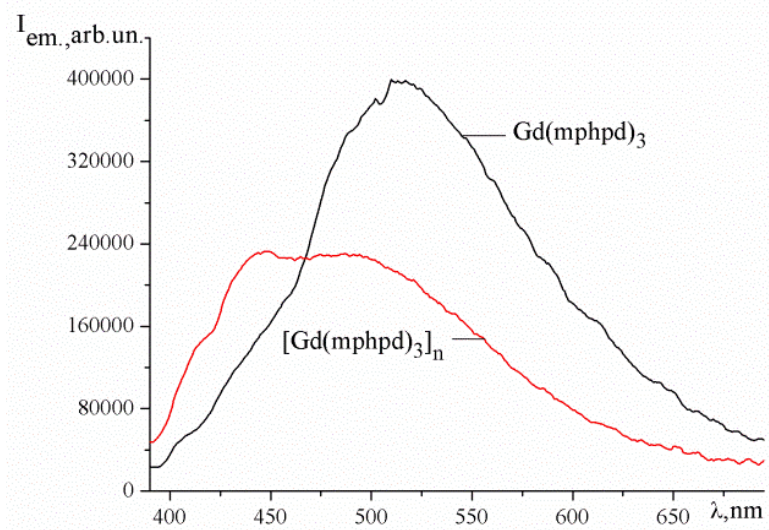

Fig. 6. Fluorescence (a) and phosphorescence spectra of the $\mathrm{Gd}(\mathrm{mphpd})_{3}$ complex $\left(\mathrm{CHCl}_{3}\right.$ solution, $\lambda=380 \mathrm{~nm})$.

The fluorescence spectrum of $\mathrm{Gd}(\mathrm{mphpd})_{3}$ contains one structureless diffuse band with maxima at 450,467 , and $482 \mathrm{~nm}$. The phosphorescence spectrum of the $\mathrm{Gd}(\mathrm{mphpd})_{3}$ complex is a broad band with two maxima at 505 and $515 \mathrm{~nm}$. It was found that for gadolinium methacroylacetophenonate, the energies of the singlet $\mathrm{S}_{1}$ and triplet $\mathrm{T}_{1}$ levels are $22150 \mathrm{~cm}^{-1}$ and $19520 \mathrm{~cm}^{-1}$, respectively (table 5). Similar studies were carried out for all gadolinium complexes. It should be noted that the similarity between the excitation and fluorescence spectra for complexes with mphpd and mbphpd, which is associated with the same nature of the substituents in the diketonate fragment. The fluorescence spectrum of the polymer sample 
$\left[\mathrm{Gd}(\mathrm{mphpd})_{3}\right]_{\mathrm{n}}$ (Fig.7). Contains one diffuse band with maxima at $431,447,461 \mathrm{~nm}$. The position of the maxima in the $\left[\mathrm{Gd}(\mathrm{mphpd})_{3}\right]_{\mathrm{n}}$ phosphorescence spectrum (Fig.7) At $419 \mathrm{~nm}$ (shoulder), $449 \mathrm{~nm}$, and $484 \mathrm{~nm}$ indicates that the energies of the singlet levels of the monomeric and metal-polymer complexes are close. Comparing the energy of the levels for the monomeric and polymer complexes of gadolinium (Table 5), it can be seen that polymeri- zation causes an increase in the energy of exciting levels by $\sim 1300 \mathrm{~cm}^{-1}$, which is associated with the delocalization of the electron density in the ligand molecule.

For gadolinium complexes with mbphpd, we also recorded the fluorescence and phosphorescence spectra, as well as excitation and emission spectra (Fig. 6). The calculated energies of the singlet and triplet levels of all ligands are given in the table 5 .

Table 5

\section{Calculated energies of the singlet and triplet levels of the studied ligand systems.}

\begin{tabular}{l|l|l}
\hline \hline Compounds & $\mathrm{E}_{\mathrm{S1}} \mathrm{cm}^{-1}$ & $\mathrm{E}_{\mathrm{T} 1,} \mathrm{~cm}^{-1}$ \\
\hline $\mathrm{Gd}(\mathrm{mphpd})_{3}$ & 22150 & 19520 \\
{$\left[\mathrm{Gd}(\mathrm{mphpd})_{3}\right]_{\mathrm{n}}$} & 23400 & 20800 \\
$\mathrm{Gd}(\mathrm{mbphpd})_{3}$ & 22360 & 19960 \\
{$\left[\mathrm{Gd}(\mathrm{mbphpd})_{3}\right]_{\mathrm{n}}$} & 23580 & 21300 \\
\hline \hline
\end{tabular}
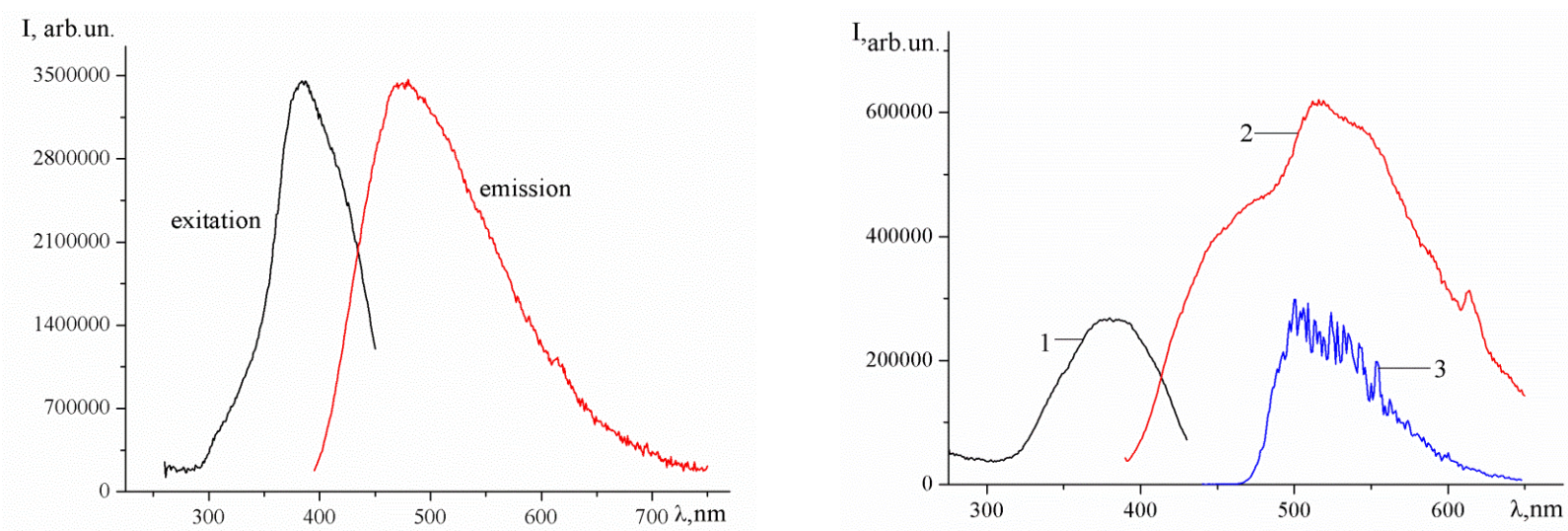

Fig. 7. Exitation $\left(\lambda_{\text {em }}=453 \mathrm{~nm}(1)\right.$ and emission at $293 \mathrm{~K}(2)\left[\mathrm{Gd}(\mathrm{mphpd})_{3}\right]_{\mathrm{n}}\left(\lambda_{\text {ex }}=380 \mathrm{~nm}\right)(\mathrm{a})$ and $77 \mathrm{~K}(3)$ of $\mathrm{Gd}(\mathrm{mbphpd})_{3}$ (b) $\left(\mathrm{CHCl} 3, \lambda_{\text {ex. }}=380 \mathrm{~nm}\right)$.

Considering the close energies of the triplet levels of the ligand systems and the resonance level of $\mathrm{Dy}^{3+}\left(21000 \mathrm{~cm}^{-1}\right)$, low emission characteristics should be expected. The recorded emission spectra confirm this assumption. As can be seen from Fig. 8b, the intrinsic luminescence intensity of the ligand is rather high and is observed in the visible region of the spectrum next to the characteristic emission band of dysprosium.

Taking into account the excitation spectrum (Fig. 8a), it is advisable to record the emission spectra with exciting different wavelengths. As can be seen from Fig. 8b, upon ex- 
citation at a wavelength of $375 \mathrm{~nm}$, a broad band is present in the emission spectrum, which corresponds to the intrinsic emission of the ligand. At $\lambda=329 \mathrm{~nm}$, we observe a decrease in the emission of the ligand, but the appearance of emission bands of the dysprosium ion. For the $\mathrm{Dy}^{3+}$ ion, the characteristic emission $c$ transitions ${ }^{4} \mathrm{~F}_{5 / 2} \rightarrow{ }^{6} \mathrm{H}_{\mathrm{J} / 2}$; $\mathrm{J}=9,11,13,15$. So with a maximum $\left(\lambda_{\mathrm{em}}=\right.$ $479-482 \mathrm{~nm}$ corresponds to ${ }^{4} \mathrm{~F}_{9} \rightarrow{ }^{6} \mathrm{H}_{15 / 2}$ magnetic dipole transition and the band $\lambda_{\mathrm{em}}=$
$572-574 \mathrm{~nm}$ (yellow-light) is characteristic of ${ }^{4} \mathrm{~F}_{9} \rightarrow{ }^{6} \mathrm{H}_{13 / 2}$ electric dipole transition. Thus, the excitation wavelength has a significant effect on the emission characteristics of metal complexes. In this regard, it is necessary to choose the correct excitation wavelength, which will reduce the luminescence intensity of the ligand and increase the metal complex. Unfortunately, for monomeric complexes with both ligands, the emission spectra could not be recorded for high ligand fluorescence.

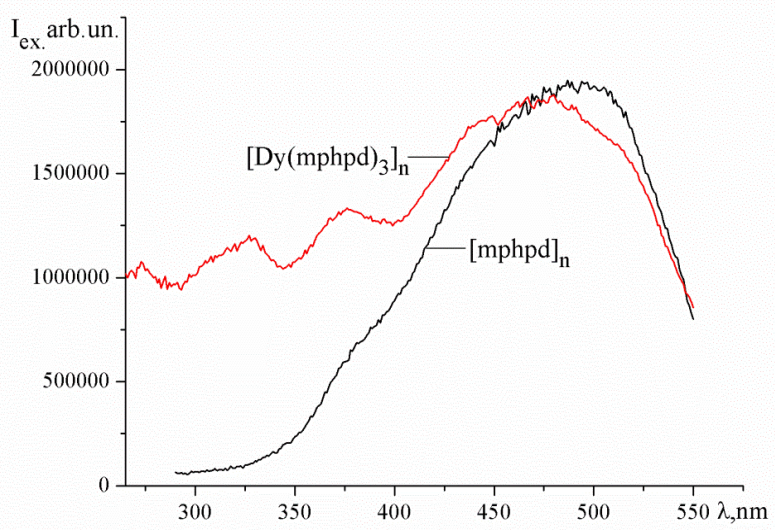

Fig. 8a. Exitation spectra of polymers (ligand and complexes).

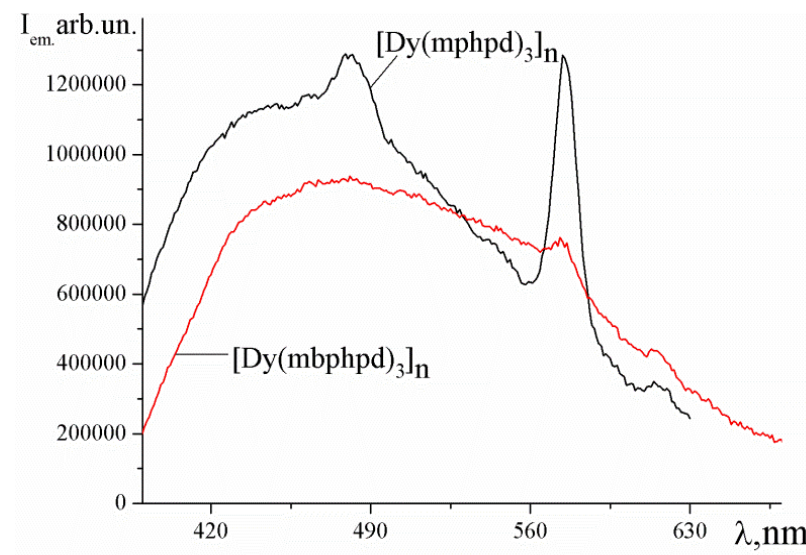

Fig. 8c. Emission spectra of complexes $\lambda_{\text {ex }}=$ 329 Hм $\left(\left[\mathrm{Dy}(\mathrm{mphpd})_{3}\right]_{\mathrm{n}}\right) \lambda_{\text {ex. }}=355$ Hм ([Dy $(\mathrm{mbph}-$ $\left.\left.\mathrm{pd})_{3}\right]_{\mathrm{n}}\right)$.

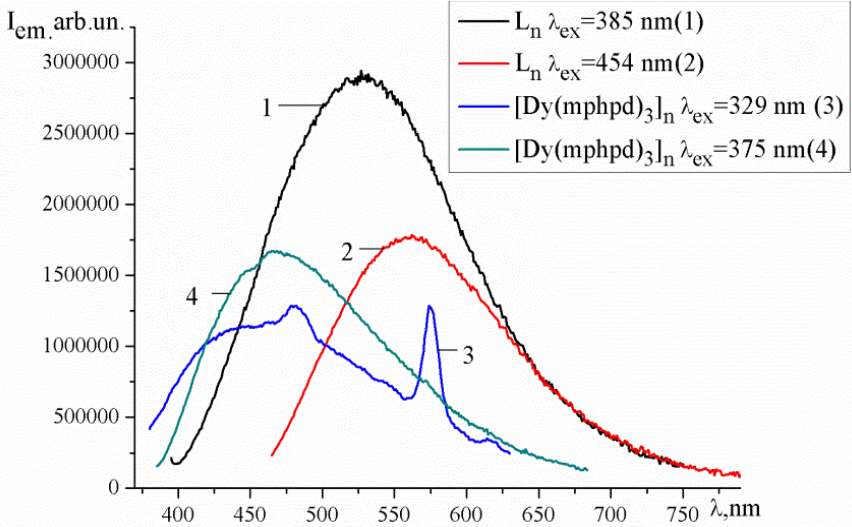

Fig. 8b. Emission spectra of polymer ligand and complexes at other exatation.

Comparing the emission spectra of metalopolymers with various ligands in Fig. 8c, it can be seen that the introduction of large aryl substituents probably has a negative effect on the emission characteristics of the compounds. Through the shielding of the emitting centers, and a low energy gap between the levels.

It is known that by changing the particle size or surface morphology, one can completely change their properties, which makes it possible to obtain systems of a given composition with predictable properties. A change in the 
dispersion can also have affect on the luminescent characteristics of the complexes. The method of dynamic light scattering makes it possible to establish the dispersion and stability of dispersed systems in solution. The method of dynamic light scattering was used to determine the particle size of complexes dissolved in dimethylformamide at $25{ }^{\circ} \mathrm{C}$ with Zeta Sizer Malvern. The studies carried out have shown that the obtained systems are rough polydisperse systems, the reproducibility of the results is low. Micrographs were recorded to establish the surface morphology. Mi- crophotographs were recorded on a scanning electron microscope (SEM) Tescan Mira 3. For polymer complexes, as in most cases, the characteristic larger particle size is due to agglomeration. When passing from a monomeric to a polymer sample, the surface morphology remains unchanged, the structure is layered. The surface structure of monomeric complexes is not uniform, which indicates the presence of agglomerated particles, and, as a consequence, an increase in the size of individual groups. In general, photomicrographs of test samples are similar to those previously described.
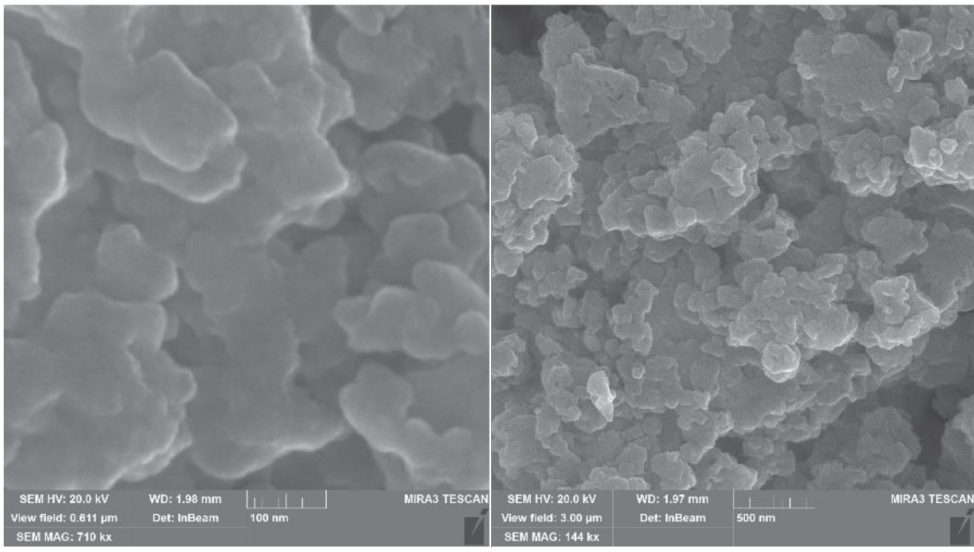

a
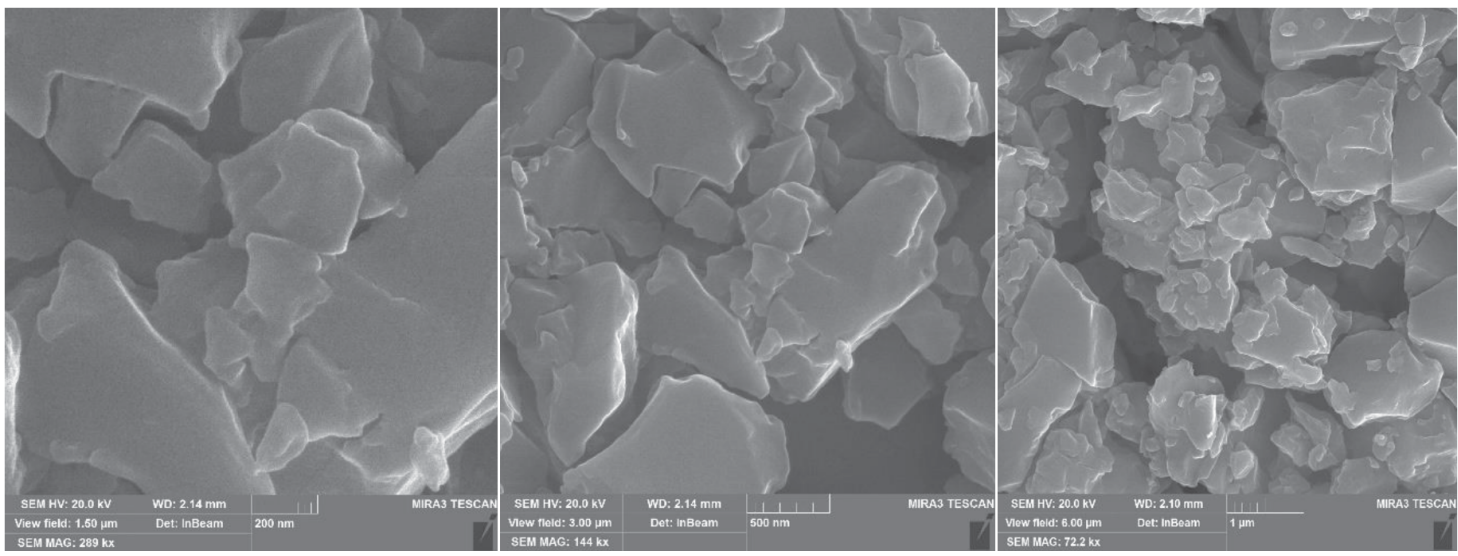

b

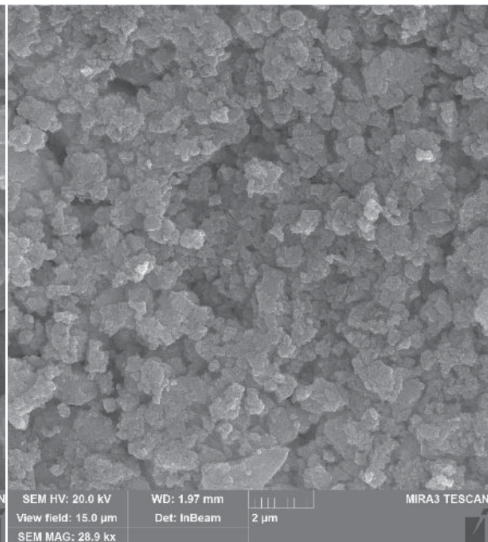

Fig. 9. SEM microphoto of the povders $\mathrm{Gd}(\mathrm{mbphpd})_{3}(\mathrm{a}),\left[\mathrm{Gd}(\mathrm{mbphpd})_{3}\right]_{\mathrm{n}}$ (b) scale label 100nm, 500nm, 2 micron, 1 micron. 


\section{Conclusion}

It was established the hydration composition, the structure and symmetry of the nearest coordination environment of the central atom in coordination compounds GD (III) and Dy(III) with $\beta$-diketones. The spectral-luminescent characteristics of obtained monoand poly dysprosium complexes exhibit a low luminescence intensity in the visible region of the spectrum, connected with close energies the triplet level of the ligand, and the singlet level of the emitting ion. It is shown that at different excitation wavelengths presence different emission characteristics. The resulting systems are coarsely dispersed amorphous powders with a layered structure.

\section{Acknowledgments}

This work was supported by funding from the National Academy of Sciences of Ukraine (318 E - program), "Creation of new multifunctional nanomaterials based on coordination compounds of 3d-metals and lanthanides with $\mathrm{O}, \mathrm{N}$-donor ligands".

The authors are grateful to Professor Irina Savchenko of the Macromolecular Chemistry Department of the Faculty of Chemistry of the National Taras Shevchenko University of Kyiv for help in the synthesis of metal polymers.

\section{КООРДИНАЦЙН СПОЛУКИ GD ${ }^{3+}$ TA DY $^{3+}$ 3 ДЕЯКИМИ $\beta$-ДИКЕТОНАМИ}

О. С. Бережницька, А. Е. Горбенко,

О. О. Роговцов, С. С. Смола, Я. В. Федоров, О. Е. Чигиринець, О. К. Трунова

${ }^{1}$ Інститут загальної та неорганічної хімї ім. В. I. Вернадського НАН Украӥни, просп. Академіка Палладіна, 32/34, Київ 03142, Украйна

${ }^{2}$ Національний технічний університет Украӥни "Київський політехнічний інстиmут імені Ігоря Сікорського”, просп. Перемоги, 37, Київ 03056, Украӥна

${ }^{3}$ Фізико-хімічний Інститут імені О. В. Богатського НАН Украӥни, вул. Люстдорфсъка дорога, 86, Одеса 65080, Україна

Синтезовано нові комплекси Dy(III) та Gd(III) $з \beta$-дикетонами, що містять ненасичені та арильні замісники. Виконано квантово-хімічні розрахунки молекул лігандів і металокомплексів. Розраховано основні енергетичні характеристики молекул лігандів: ентальпія утворення, повна енергія молекули та довжини зв'язків, параметри електронної заселеності лігандів. Розраховані енергії вищої заповненої молекулярної орбіталі $\left(\mathrm{E}_{\text {номо }}\right)$ i нижчої вакантної молекулярної орбіталі ( $\left.\mathrm{E}_{\mathrm{LUMO}}\right)$ свідчать про слабкі електроноакцепторні властивості комплексів.

Методом радикальної полімеризації отримано металополімери на основі синтезованих комплексів. Встановлено склад та будову синтезованих комплексів та металополімерів. Показано, що при полімеризації 
координаційне оточення центрального іона залишається незмінним. Ліганди координуються до центральних іонів бідентатнохелатно, утворюючи трис-комплекси. К.ч. іонів гадолінію (III) та диспрозію (III) дорівнює 8, координаційна сфера доповнюється двома молекулами води. Досліджено спектрально-люмінесцентні характеристики синтезованих сполук. Визначено енергії триплетного рівня мономерних та полімерних лігандів. Наявність молекул води в найближчому координаційному оточенні зумовлює низьку інтенсивність емісії мономерних комплексів диспрозію. В спектрах люмінесценції металополімерів присутні смуги magnetic dipole transition $\left({ }^{4} \mathrm{~F}_{9} \rightarrow{ }^{6} \mathrm{H}_{15 / 2}\right)$ and electric dipole transition $\left({ }^{4} \mathrm{~F}_{9} \rightarrow{ }^{6} \mathrm{H}_{13 / 2}\right)$. Близькі енергії триплетного рівня ліганду та резонансного рівня іона диспрозію зумовлюють невисокі емісійні характеристики синтезованих комплексів диспрозію. Дослідження морфології та дисперсності наносистемы, отриманих на основі синтезованих сполук, свідчить про великий розмір часток та полідисперсність, що зумовлено наявністю громіздких замісників та агломерації. Структура поверхні частинок $\epsilon$ шаруватою.

Ключові слова: лантаніди, комплекси, люмінесцентні властивості, металополімери, гадоліній, диспрозій, $\beta$-дикетони.

\section{REFERENCES}

1. Santos P.R.S., Pereira D.K.S., Costa I.F., Silva I.F., Brito H.F., Faustino W.M., Carneiro Neto A.N., Moura Jr. R.T., Araújo M.H., Diniz R., Malta O.L., Teotonio E.E.S., Experimental and theoretical investigations of the $\left.\left[\mathrm{Ln}(\beta \text {-dik })\left(\mathrm{NO}_{3}\right)_{2} \text { (phen }\right)_{2}\right] \cdot \mathrm{H}_{2} \mathrm{O}$ luminescent complexes, Journal of Luminescence. 2020. doi: https://doi.org/10.1016/j. jlumin.2020.117455.

2. Mikhalyova E.A., Zeller M., Jasinski J.P. at all Combination of single-molecule magnet behaviour and luminescence properties in a new series of lanthanide complexes with tris(pyrazolyl)borate and oligo( $\beta$-diketonate) ligands. Dalton Transactions. 2020. 49(23): 7774-7789.

3. Dascalu I.A, Mikhalyova E.A., Shova S., Lozan V., Roman G. at all. Synthesis, crystal structure and luminescent properties of isoreticular lanthanide-organic frameworks based on a tetramethyl-substituted terphenyldicarboxylic acid Polyhedron. 2021. 194: 114929.

4. Sukhikh T.S., Kolybalov D.S., Pylova E.K., Bashirov D.A., Komarov V.Y., Kuratieva N.V., Smolentsev A.I.,Fitch A.N., Konchenko S.N. A fresh look at the structural diversity of dibenzoylmethanide complexes of lanthanides. New J. Chem. 2019. 43: 9934-9942. doi: 10.1039/C9NJ02059D.

5. Abdallah. A., Freslon S., Fan X., Rojo A., Daiguebonne C., et al. Lanthanide-Based Coordination Polymers With 1,4-Carboxyphenylboronic Ligand: Multiemissive Compounds for Multisensitive Luminescent Thermometric Probes. Inorganic Chemistry, American Chemical Society. 
2019. 58(1): 462-475. ff10.1021/acs.inorgchem.8b02681.

6. Zhang J., Li J., Feng X., Kong M., Hu Z.-B., Zheng Y.-X., Song Y. Light-controlled efficient photoluminescence based on an europium b-diketonate complex with single-crystal-to-single-crystal [2+2] cycloaddition. Chem. Commun. 2019. 55: 12873-12876. doi: 10.1039/c9cc05227e.

7. Kumar K., Stefańczyk O., Chorazy S., K. Nakabayashi, B. Sieklucka, S. Ohkoshi Effect of Noble Metals on Luminescence and Single-Molecule Magnet Behavior in the Cyanido-Bridged Ln-Ag and Ln$\mathrm{Au}$ ( $\mathrm{Ln}=\mathrm{Dy}, \mathrm{Yb}, \mathrm{Er})$. Complexes Inorg. Chem. 2019. 58(9): 5677-5687. https://doi. org/10.1021/acs.inorgchem.8b03634.

8. Yao X., An G., Li Y., Yan P., Li W., Li G. Effect of nuclearity and symmetry on the single-molecule magnets behavior of seven-coordinated $\boldsymbol{\beta}$-diketonate Dy(III) complexes. Journal of Solid State Chemistry. 274: 259-302. https://doi.org/10.1016/j. jssc.2019.03.044.

9. Shi, Q.-H., Xue C.-L., Fan C.-J., Yan L.-L., Qiao N., Fang M., Wang S.-F., Magnetic refrigeration property and slow magnetic relaxation behavior of five dinuclear $\mathrm{Ln}$ (III)-based compounds. Polyhedron. 2021. 194: 114938. https://doi.org/10.1016/j.poly. 2020.114938.

10. Fondo M., Corredoira-Vázquez J., Herrera-Lanzós A., García-Deibe A.M., Sanmartín-Matalobos J., Manuel Herrera J., Colacio E., Nuñeza C. Improving the SMM and luminescence properties of lanthanide complexes with $\mathrm{LnO}_{9}$ cores in the presence of $\mathrm{Zn}^{\mathrm{II}}$ : an emissive $\mathrm{Zn}_{2}$ Dy single ion magnet. Dalton Trans. 2017. 46: 17000-17009.

11. Pavlishchuk V.V. Influence of Structure on Magnetic and Photoluminescent Properties of Coordination Compounds of 3d- and 4f-Metals and Nanocomposites Based on Them. Theoretical and Experimental Chemistry. 2017. 53(5): 296-304.

12. Eliseeva S.V., Bunzli J.C.G. Lanthanide luminescence for functional materials and bio-sciences. Chemical Society Reviews. 39(1): 189-227.

13. Fouad R., El-Shafiy H.F., Photoluminescence and cytotoxicity properties of new quinolinone lanthanide nano-complexes, Journal of Molecular Structure. 2019. 1190: 68-76. doi: https:// doi.org/10.1016/j.molstruc.2019.04.051.

14. Sato T., Higuchi M. Efficient white-lightemission from a heterometallo-supramolecular polymer with $\mathrm{Eu}(\mathrm{III})$ and $\mathrm{Zn}(\mathrm{II})$ ions introduced alternately. Tetrahedron Letters. 60(13): 940-943. https://doi. org/10.1016/j.tetlet.2019.02.044

15. Shia Q., Liub J., Wanga J., Yanga X., Zhanga X., Lia S., Suna P., Chena J., Lia B., Lüb X., Color-tunable white-light of binary tris- $\beta$-diketonate- $(\mathrm{Dy} 3+, \mathrm{Gd} 3+\mathrm{x})$ complexes' blend under single wavelength excitation. Inorganic Chemistry Communications. 2020. 113: 107814. https://doi. org/10.1016/j.inoche.2020.107814

16. Wang L.P., Du H.Y., Wang Y.X., Wang M., Tian Z.L., White-light-emitting single component metal-organic frameworks based on 2,3-pyridinedicarboxylic acid, Integr. Ferroelectr. 200 (2019): 199-227.

17. Wei C., Yao X., Sun B., Cai Z., Zhao Z., Chen M., Wei H., Liu Z., Bian Z., Huang C., Evaporable luminescent lanthanide complexes based on novel tridentate ligand. Journal of Rare Earths. 2021. 35(1): 7-14. https:// doi.org/10.1016/S1002-0721(16)60166-7. 
18. Nikolaeva A., Nygaard R., Martynova I., Tsymbarenko D. Synthesis, structure and thermal behavior of volatile mononuclear mixed ligand complexes of rare-earth dipivaloylmethanates with diethylenetriamine. Polyhedron. 2020. 180: 114373, https://doi. org/10.1016/j.poly.2020.114373.

19. Laura A. G., Wada, Lee S.C., Sobolev A.N., Hasegawa Yu., ,Eli Z.-C., Massi O. M., at all. Photophysical investigation of near infrared emitting lanthanoid complexes incorporating tris(2-naphthoyl)methane as a new antenna ligand. Dalton Transactions. 2019. 48: 3768-3776. 10.1039/C8DT04749A.

20. Meshkova S. B., The Dependence of the Luminescence Intensity of Lanthanide Complexes with $\beta$-Diketones on the Ligand Form, J. of Fluorescence. 2000. 10: 333-337. https://doi.org/10.1023/A:1009418227641/.

21. Gontcharenko V. E., Kiskin M.A., Dolzhenko V. D., Korshunov V.M., Taydakov I.V., Belousov Y.A. Mono- and Mixed Metal Complexes of $\mathrm{Eu}^{3+}, \mathrm{Gd}^{3+}$, and $\mathrm{Tb}^{3+}$ with a Diketone, Bearing Pyrazole Moiety and CHF2-Group: Structure, Color Tuning, and Kinetics of Energy Transfer between Lanthanide Ions. Molecules. 2021. 26: 2655-2669. https://doi.org/10.3390/ molecules26092655.

22. Pan M., Du B.B., Zhu Y.X., Yue M.Q., Wei Z.W., Su C.Y., Highly efficient visible-toNIR luminescence of lanthanide(III) complexes with zwitterionic ligands bearing charge-transfer character: beyond triplet sensitization. Chem. Eur. J. 2016. 22: 2440-2451.

23. Olyshevets I., Kariaka N., Znovjyak K., Gerasimchuk N., Lindeman S., Smola S., Seredyuk M., Sliva T., Amirkhanov V.,
Synthesis and Characterization of Anionic Lanthanide(III) Complexes with a Bidentate Sulfonylamidophosphate (SAPh) Ligand, Inorg. Chem. 2020. 59(1): 76-85. https://doi.org/10.1021/acs.inorgchem.8b02846.

24. Litsis O., Ovchynnikov V., Sliva T., Amirkhanov V., Sorokin V., Minyailo M., Kolomzarov Yu., Tytarenko P., Minakova I., Europium coordination compounds based on carbacylamidophosphate ligands for metal-organic light-emitting diodes (MOLEDs), Semicond. Phys. Quantum Electron. Optoelectron. 2013. 16(2): 210-215. https://doi.org/10.15407/ spqeo16.02.210.

25. Savchenko I.O., Berezhnytska O.S., Fedorov Ya., New polymer metal complexes based $\beta$-diketones and lanthanides for OLEDs In book: Chem. Engineering of Pol. Product. of Func. and Flexible Mater., Apple Academic Press.19. 2017. 40-51 https://doi.org/10.1201/9781315365985.

26. Berezhnytska O., Savchenko I., Denysova Z., Rusakova, N., Fedorov, Ya., Veligura, L., Rogovtsov, O.,Trunova, E. The new nanosized system on the basis Eu(III) complexes as precursors for organic electroluminescence diodes. Molecular Crystals and Liquid Crystals. 2014. 590: 58-65. https://doi.org/10.1080/15421406 .2013.873848.

27. Igoa F., Peinado G., Suescun L., Kremer C., Torres J., Design of a white-light material based on a mixed-lanthanide metal organic framework, J. Solid State Chem. 279 (2019): 120925.

28. Li J.J., Fan T.T., Qu X.L., Han H.L., Li X., Temperature-induced 1D lanthanide polymeric frameworks based $\operatorname{Ln}_{n}(n=2,2,2,6)$ 
cores: synthesis, crystal structures and luminescent properties. Dalton Trans. 2016. 45: 2924-2935.

29. Fan L.M., Fan W.L., Li B., Zhao X., Zhang X.T., W-shaped 1,3-di(2,4-dicarboxyphenyl)benzenebased lanthanide coordination polymers with tunable white light emission, New J. Chem. 2016. 40: 1044010446.

30. Dang S., Zhang J.H., Sun Z.M., Tunable emission based on lanthanide(III) metalorganic frameworks: an alternative approach to white light. 2012. J. Mater. Chem. 22: 8868-8873.

31. Tweedle M.F. Physicochemical properties of gadoteridol and other magnetic resonance contrast agents. Invest Radiol. 1992. 27: 2-6.

32. Runge V.M. A comparison of two MR hepatobiliary gadolinium chelates, Gd-BOPTA and Gd-EOB-DTPA. Journal of Computer Assisted Tomography. 1998. 22: 643-650.

33. Tweedle M.F. The ProHance story: the making of a novel MRI contrast agent. European Radiology. 1997. 7: 225-230.

34. Raymond K.N, Pierre V.C. Next generation, high relaxivity gadolinium MRI agents. Bioconjug Chem. 2005. 16: 3-8.

35. Runge V.M, Dickey K.M, Williams N.M, Peng X. Local tissue toxicity in response to extravascular extravasation of magnetic resonance contrast media. Invest Radiol. 2002. 37: 393-398.

36. Xu, Q. Gadolinium(III) chelated conjugated polymer as a potential MRI contrast agent / Q. Xu, L. Zhu, M. Yu, F. Feng, L. An, C. Xing, S. Wang Polymer. 2010. 51(6): 1336-1340.

37. Liu, Y. Gadolinium-loaded polymeric nanoparticles modified with Anti-VEGF as multifunctional MRI contrast agents for the diagnosis of liver cancer / Y. Liu, Z. Chen, C. Liu, D. Yu, Z. Lu, N. Zhang Biomaterials. 2011. 32(22): 5167-5176.

38. Savchenko I., Berezhnytska O.S., Fedorov Ya, Smola S., Trunova O. Luminescent properties of new polymer metal complexes based $\beta$-diketones and REE. Molecular Crystals and Liquid Crystals. 2018. 673(1): 48-60. https://doi.org/10.1080/15421406. 2019.1578493.

39. Berezhnytska O.S., Savchenko I.O., Ivakha N.B., Trunova O.K., Smola S.S., Zheleznova L.I. Near infrared electroluminescence polymeric systems containing $\beta$-diketones and lanthanides as emitters for organic light - emitting diodes. Molecular Crystals and Liquid Crystals, 2018. 670(1): 48-60. https://doi.org/10.1080/15 421406.2018.1542061.

40. Fedorov Ya.V., Berezhnytska O.S., Trunova O. K., Melnyk O.V., Synthes and study of europium complexes and metalopolymers based on. Ukr. Khim. Journal. 2013. 79(3): 25-31.

41. Mishchenko A.M., Trunova O.K., Semiempirical calculation of the structure of tautomeric forms of aliphatic $\beta$-ketoesters. Ukr. Khim. J. 81(10): 73-80.

42. Mishchenko A.M., Trunova, E.K., Berezhnytska A.S., Lanthanide complexes with allyl acetoacetate in mixed water-organic media: Formation, stability and bonding. Journal of Solution Chemistry. 2015. 44(11): 2117-2128. https://doi. org/10.1007/s10953-015-0396-z.

43. Movchan, T.I., Solovyov, T.I., Petrova, L.A., Voloshanovsky, I.S., Belov, G.P., Pomoghailo A.D. Izv. AN, Ser. Chem. 1994. 1: 43-47. 
44. I. Savchenko, A. Berezhnytska, E. Trunova, N. Rusakova, Ya. Fedorov, G. Grozduyk Poly complexes based unsaturated $\boldsymbol{\beta}$-diketones and rare earth elements for optoelectronics. Molec. Crys. Liqud. 2016. 640. http://dx.doi.org/10.1080/15421406.2016. 1257311.

45. Nakamoto K., Infrared spectroscopy of inorganic and coordination compounds. Mir. Moscow. 1991.

46. Nekhoroshkov V.P., Kamalov G.L., Zhelt- vay I.I., Ososkov A.K., Berestetskaya E.D., On the interaction between the IR spectral properties of $3 \mathrm{~d}$-transition metal $\beta$-diketonates and their structure. Russ. J.Coord. Chim. 1984. 10(4): 459-465.

47. Nakamoto K., McCarthy P. J., Martell A.E., Infrared Spectra of Metal Chelate Compounds. III. Infrared Spectra of Acetylacetonates of Divalent Metals. J. Am. Chem. Soc. 1961. 83(6): 1272-1276. https://doi. org/10.1021/ja01467a003

Стаття надійшла 01.07.2021. 